\title{
Take me to your leader: Using socio-technical energy transitions (STET) modelling to explore the role of actors in decarbonisation pathways
}

Accepted Manuscript: $16^{\text {th }}$ January 2019

Published in: May 2019, Energy Research \& Social Science, Volume 51, Pages 67-81, doi: 10.1016/j.erss.2018.12.010

Francis G. N. Lia , francis.li@ucl.ac.uk

Neil Strachana, n.strachan@ucl.ac.uk

a UCL Energy Institute, Central House, ${ }_{4}$ Upper Woburn Place, London, WC $1 \mathrm{H}$ oNN, United Kingdom

(C) 2019. This manuscript version is made available under the CC-BY-NC-ND 4.0 license http://creativecommons.org/licenses/by-nc-nd/4.0/

\begin{abstract}
Quantitative modelling analysis in support of national and global decarbonisation pathways has never been more important to achieving global climate stabilisation in line with the Paris Agreement. However, established equilibrium and optimisation models tend to radically simplify their depiction of societal and political/institutional actors. This can make them difficult to use for implementing specific energy and climate policies in the near term and aligning these with long term targets. Most energy systems analysis continues to pair such techno-economic models with entirely qualitative narratives about future political and societal developments. The result is that these critical factors often fade into the background in subsequent discourse. In this paper, we utilise BLUE - a leading socio-technical energy transition (STET) model of the United Kingdom' $s$ (UK) energy system - to capture elements of the heterogeneity, consistency and co-evolution of societal and political drivers. We focus specifically on exploring government-led and societally-led energy transitions and investigating the differences in their decarbonisation pathways and end states. Our modelling exercise finds that it is not who leads per se that is the most critical, but rather the level of the initial effort and subsequent commitment from both leader and follower actors that appears to regulate the pace at which decarbonisation pathways unfold. However, systemic inertia in all cases means that the deepest decarbonisation targets continue to appear very difficult to achieve.
\end{abstract}

\section{Keywords}

Socio-technical transitions; Energy modelling; Climate Policy; Behaviour; 


\section{Highlights}

- Energy modellers must rise to the challenges of capturing political dynamics, human behaviour, and social change

- We present STET model scenario analysis of government-led and societally-driven transitions towards low carbon futures

- Co-evolutionary elements of government decision making and societal change are endogenised inside the model boundary

- Government-led and societally-driven pathways exhibit different dynamics and support different conclusions

- Depicting the role of actors in energy models is critical as decision making moves from target setting to implementation

\subsection{Introduction}

\subsection{The socio-technical nature of energy transitions}

Energy policy in the 21st century calls for the resolution of multiple, often competing objectives, under a shifting landscape of political, economic and technological challenges. Against a global backdrop of population growth, increasing urbanisation, and increasing competition for raw materials, national governments are striving for socioeconomic development and resource security while nominally seeking to also arrest accelerating environmental decline. A critical pillar of global environmental negotiations remains humanity's ongoing response to anthropogenic warming. The science on climate change mitigation demands an urgent and rapid requirement for the decarbonisation of energy use [1]. The 2015 Paris Agreement and the UNFCCC process [2] formalises a mechanism by which national governments will be required to incrementally report on their proposed strategies for transforming their economies towards zero-emissions states. If successfully implemented [3], this new global policy imperative has the potential to disrupt established technologies and transform longestablished institutional and governance arrangements for energy.

Decarbonisation appears to be a pre-requisite for bringing current levels of human activity within planetary boundaries. In light of this requirement, studies have sought to understand whether or not the established pattern for large-scale technological change, which almost invariably takes many decades to occur [4], can be circumvented or not $[5,6]$. The complexity of energy systems makes efforts to accelerate far reaching systemic change extremely daunting [7], as does the strength of the incumbent fossil fuel regime [8], although there is some optimism that active policy management (as opposed to passive governance) might enable future transitions to be more rapid than those observed historically [9].

Transitions studies $[10,11]$ have often pondered the question of whether the overall pace of change is driven primarily by technological or societal elements. A key insight from historical transitions analysis is that while the performance and costs of new technologies were powerful determinants for their eventual success or failure, so also 
were the relationships between innovations and the political and cultural landscape of the day, as well as the strategies employed by the actors and institutions which supported them [12-14]. In other words, the evidence from economic history suggests that technological transitions are inherently socio-technical. There is no logical reason to suppose a priori that future technological transitions will be any different and yet the socio-technical nature of transitions continues to be routinely overlooked in many energy policy discussions $[15,16]$.

\subsection{Modelling energy transitions towards climate targets}

Analytical models have a long history being applied to explore technological options for global climate stabilisation. Models typically show that internationally agreed targets (such as the $1.5^{\circ} \mathrm{C}$ and $2^{\circ} \mathrm{C}$ goals in the Paris Agreement) are extremely difficult to meet and require rapid, sustained, and early action, global collaboration on mitigation efforts and the rapid diffusion of key energy technologies $[17,18]$. The implementation of near-term climate policies that are consistent with long term targets is therefore critical. But conventional energy policy models are typically difficult to use for socio-technical analysis, and for understanding the role of different present day actors and institutions in future transitions $[19,20]$.

The common practices of either radically simplifying actor behaviour, or leaving actor decisions outside of the scope of models (discussed further in Section 2.0), avoids apportioning responsibilities to specific societal or political actors and institutions. This leaves significant ambiguity about who exactly must do what in path-dependent transitions i.e. transitions where successive choices act to constrain or open-up future options [21,22]. As leaders are often not identified, it is not obvious which parties hold the responsibility for overcoming socio-political inertia $[23,24]$ and breaking the existing system out of it's locked-in state $[25,26]$. This impedes important societal discourse on how to bring about future transitions, and makes the alignment of near term actions with long term climate targets extremely challenging.

\subsection{Aims and objectives}

This paper focuses on exploring whether and how energy system analysis can be broadened to better encompass the socio-political dimension by assigning roles to different actors in path-dependent transitions modelling. The energy modelling research community ${ }^{1}$ that feeds into global debate on energy and climate policy is forward looking, self-reflective, and receptive to critique. There are continuing efforts to improve the representation of human behaviour and decision making in complex

\footnotetext{
${ }^{1}$ Exemplified (but of course not limited to) groups such as the Integrated Assessment Modelling Consortium (IAMC, http://www.globalchange.umd.edu/iamc/), the Deep Decarbonisation Pathways Project (DDPP, http://deepdecarbonization.org/about/), the International Energy Agency's Energy Technology Systems Analysis Programme (IEA-ETSAP, http://iea-etsap.org/) the OpTIMUS community (http://www.optimus.community/) or the Open Energy Modelling Initiative (openmod, http://www.openmod-initiative.org/)
} 
system models. However, little formal guidance exists on how to consider critical aspects of energy futures, such as societal change and political dynamics, in formal socio-technical energy transitions (STET) models (elaborated on in Section 2.0). This is largely because these tools are few in number relative to more conventional techno-economic equilibrium and optimisation models, and have yet to enter widespread use or feed into major policy debates.

In this paper, we undertake a critical first step towards reformulating the treatment of the socio-political dimension in energy modelling, and report on our attempts to do so with a complex system model of the UK energy system as a case study. As a means of stimulating conceptual and methodological innovation in this area, we have framed our analysis around a simple question. Should government or society lead the energy transition? The leader-follower question is a useful framing for the energy transition challenge. Can national governments direct the process of technological change from the "top-down" in order to deliver net benefits for society as a whole, or could transitions involving a much greater role for civil society and the actions of individuals bring about a transition from the "bottom-up", with government in a secondary and more reactive mode $[27,28]$ ? Specifically, we investigate:

i. Whether a socio-technical framing around the leader-follower question can be used to explore energy system transition pathways towards deeply decarbonised futures, including:

a. The influence of heterogeneous and evolving societal preferences and values.

b. Real world political challenges such as varying levels of policy consistency between different governments over time.

c. The iterative and co-evolving nature of society and political drivers.

ii. How government-led and societally-driven transitions might differ from one another and whether they might lead to similar or contrasting evolutionary trajectories and final end states.

The structure of the article is as follows. In the introduction (Section 1.0) we have outlined our rationale for taking a socio-technical approach to understanding and modelling future energy transitions. We then provide an overview of models in the policy cycle, how actors and institutions are captured in conventional models, and explore the potential role for socio-technical energy transition (STET) models (Section 2.0). We then outline the key features of the model used in the article and the modifications to previous versions that were made in order to address the leaderfollower question (Section 3.0). We then proceed to describing a series of thought experiments [29] (Section 4.0) that explore how government-led and societally-driven transitions might be implemented in a formal STET model (Section 3.0), and to assess whether or not they produce comparable or divergent transitions (Section 5.0). We then discuss general insights from the exercise before reflecting critically on its 
limitations and the potential avenues for future work (Section 6.0) before offering up our conclusions on the value of the study (Section 7.0).

2.0

2.1

\section{Socio-technical energy transitions (STET) modelling}

\section{Models in the policy cycle}

Quantitative modelling and analysis techniques are critical components of mainstream political and industrial decision making for the energy transition at the global, national, and sub-national levels. Models at these various scales serve different purposes. Global Integrated Assessment Models (IAMs) feature heavily in the work of the Intergovernmental Panel on Climate Change [30] and are used in this context for the purposes of exploring the feasibility of achieving climate targets (e.g. $[31,32])$ and therefore setting the agenda for global environmental negotiations under the United Nations Framework Convention on Climate Change (UNFCCC). However, their macro-scale and aggregate representation of different countries means that they are not typically employed for policy assessment and design, as these functions occur at the level of the nation-state [33]. National-scale models are instead used to inform national energy and climate policy activities, such as exploring sector-specific initiatives and regulations or designing new market mechanisms [34].

Even within the national-scale context however, models often come from a variety of different design philosophies that affect the type of problems that they can be applied to investigate. Energy models are usually based on real-world data grounded in either engineering processes or monetary flows (with hybrid approaches being increasingly common [35]), which gives them epistemic power in different domains. Additionally, models can be used as part of scenario analysis activities for predictive, normative, or exploratory purposes [36]. Energy models with long time horizons (extending many decades) are usually used in either a normative fashion to backcast [37] the energy system configurations that might meet desired emissions or resource targets under constraints, or an exploratory fashion to understand the possible ramifications of different policy decisions on demand, emissions or technology diffusion in different sectors. Within the context of decarbonisation pathway planning at the nation-state level, normative target-setting activities are dominated by energy system optimisation models (ESOMs [38]), while a variety of other model types can found being used for exploratory impact assessments (such as system dynamics [39] and agent-based models [40]).

\subsection{Capturing actors and institutions in models}

A majority of energy models, regardless of their scale or their design for normative or exploratory application, tend to focus on the engineering configuration of technical systems and the infrastructure that connects them together, but not on the behaviours of actors and institutions that govern them [20]. Few models in the energy and climate field explicitly acknowledge the co-evolutionary nature of policymaking, societal change, and technology (for notable exceptions see [41,42]). Most models are therefore behaviourally and societally abstract, and as a result, give insights that 
do not apportion responsibility for near-term action to present-day actors and institutions.

Models and scenarios, rightly or wrongly, inform visions, guide expectations, and shape the shared understanding of policymakers and society regarding what is and is not possible $[43,44]$. The prevalence of technology-only energy modelling in public policymaking has had the effect of narrowing the focus of the ensuing discourse more or less exclusively on energy technologies rather than their socio-political context and how rapidly they might be adopted [45]. As a result much discourse on energy transitions towards climate targets is framed as a narrow, "stunted" conversation about technologies and fuels [16] but not the role of political decisions or social change. In all likelihood, the ambitious targets outlined in the Paris Agreement cannot be achieved in all countries and in all sectors on relevant timescales by following a strategy that depends exclusively on the technological substitution of fossil fuels for carbon free alternatives $[32,46,47]$. This means that model-based analysis to support the future energy transition must also look beyond technologyonly modelling.

\subsection{Socio-technical modelling for decision-making}

To date, the energy modelling community has addressed the challenges posed by societal and political barriers to climate mitigation policies in a number of ways. Energy models are often built with historically informed perspectives on past rates of technological change, with the rationale being that this anchors the decision space covered by future model projections within the realms of socio-technical plausibility $[48,49]$. Political barriers to the implementation of climate policy are sometimes represented as time delays in mitigation (e.g. $[50,51])$ or as restrictions on the availability of critical technologies (e.g. $[52,53])$. The embedded nature of technological change within specific socio-economic contexts is captured in modelling that feeds into the IPCC reporting process through the development of shared socio-economic pathway scenarios (SSPs) [54]. Finally, there have also been a number of recent efforts to explore the integration of behavioural choice factors into existing models [55-57].

However, there remains much scope for improvement with regard to the depiction of actors, including the power and agency of individuals and governments, in energy models. Mercure et al. [22] charges that existing models are over reliant on the assumption of rational behaviour by decision makers (also see [58]), that interactions amongst actors are over simplified, and that path dependencies are inadequately accounted for. Institutional barriers and political inertia, both salient features of the real world energy system, are also often left out of models [31]. There are a number of calls in the literature to consider the development of climate policy models that feature explicit decision making agents $[59,60]$.

Efforts to improve the representation of political and societal factors in energy modelling coincides with renewed interest from the sustainability transitions community in quantitative representations of socio-technical change in energy 
systems [22]. Transitions scholars have already outlined the rationale for formal modelling of socio-technical change $[61,62]$. This renewed interest in quantification may be linked to the desire for enhanced policy impact [63].

The conceptualisation and definition of socio-technical energy transitions modelling is broad, covering the multi-level perspective [64], co-evolutionary theories [65,66], the application of complexity science [67] and the use of adaptive policy pathways [68]. A full socio-technical modelling approach would aim to capture the technoeconomic detail of the energy system, multi-level governance, the range of societal and political feedbacks, and the overlapping decisions of many decision makers. Li et al. [69] conceptualise socio-technical energy transitions (STET) modelling as an emerging research frontier where analysts attempt to capture various elements of socio-technical transitions, including societal actors and the co-evolutionary nature of policy, technology and behaviour, within a formal quantitative framework that can be operationalised for energy policy purposes. The main attributes of such models (see Figure 1) are conceived as being techno-economic detail, explicit actor heterogeneity, and transition pathway dynamics $[69,70]$.

Figure 1-A taxonomy of socio-technical energy transitions models (based on Li et al. $[69,70])$

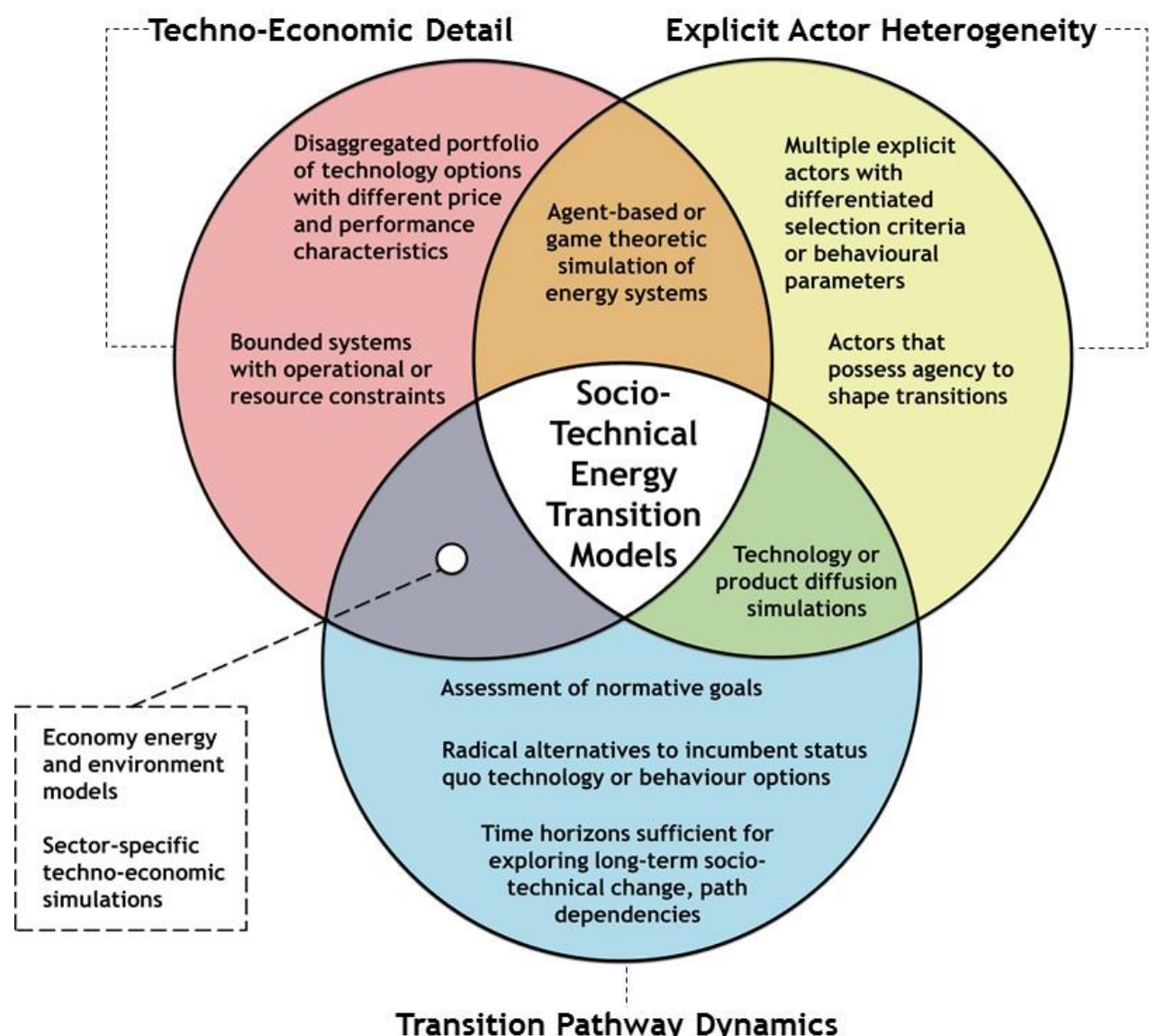

Modelling socio-technical change for energy and climate policy purposes is an interdisciplinary research field that is replete with unresolved challenges. It remains 
an open question as to what extent it is wise or possible to represent all of the relevant societal and political elements of transitions in formal models [71], or how best to pair qualitative analysis with quantitative tools [72-74]. Models that are closely aligned with or built to capture particular theories of socio-technical change (e.g. [75]) might face challenges to adoption if those same theories are challenged or disputed by the prospective audience for their work (see $[76,77])$. Where these models might fit into the policy cycle, what problems they might be used to address, and whether they will be viewed as credible, salient and legitimate $[78,79]$ by decisionmakers remains to be determined.

Models can effectively act as a "prosthesis for the imagination" [80], and as a boundary object to change beliefs and values as a facilitator of policy change [81]. One possible application for STET models that is not straightforward to achieve with conventional models could be participatory simulation [82] for the purpose of consensus building [20] amongst diverse actors in the transition. The ability of such models to explore different future roles for real-world transition actors might enable their use as powerful stakeholder engagement tools for learning [83], challenging cognitive framings $[84,85]$, and building shared narratives and visions $[86,87]$.

\section{BLUE (The Behaviour, Lifestyles and Uncertainty Energy model)}

Existing STET models [69] have tended to explore individual sub-sectors such as power generation and transport rather than attempt to provide a broader assessment of societal, political and technological change across the wider energy system. This means that few socio-technical models are able to consider the co-evolutionary nature of technology, society and policy [65] in the context of national decarbonisation initiatives and plans, such as the Nationally Determined Contributions (NDCs) required by the Paris Agreement. For our analysis in this paper we employ BLUE (the Behaviour, Lifestyles and Uncertainty Energy model), a system dynamic STET model of the UK that captures energy, emissions and technological diffusion across the whole national energy system.

BLUE can be considered an "actor-based" model, with the "dynamics of the system... dominated by the strategies of a relatively small number of key actors" [88]. The model represents multiple economic sectors as separate actors whose individual decision and interactions can affect the course of energy transitions. The model features a probabilistic formulation for exploring uncertainties in future pathways, with variation in inputs (reflecting an uncertain possibility space) easily captured in model outputs. Past publications using BLUE have focused on understanding the effect of socio-technical inertia, path dependencies and lock-in [70], and economically non-optimal behaviour on future energy transitions [89]. BLUE is a bottom-up hybrid energy system model [34] with a similar formulation to models such as CIMS [90], PRIMES [91] and POTeNCIA [92]. The model simulates the interactions of a population of representative agents, each acting to minimise their own (imperfectly) perceived discounted system costs over time in a myopic fashion. Summary model documentation, including model equations and data sources can be found at: http://www.ucl.ac.uk/energy-models/models/blue. 
BLUE can be distinguished from the majority of other STET models by its broad, multi-sectoral approach to understanding energy and climate policy trade-offs. BLUE captures energy demand across a full spectrum of end uses, including the residential, commercial, industrial and transport sectors. This whole system approach (albeit with coarse granularity) is critical for understanding economy-wide decarbonisation targets in the context of climate policy assessment.

BLUE can be used to represent many of the barriers found in so-called second-best policy environments [93] and captures a range of insights from behavioural economics in its characterisation of individual choice [94]. Obstacles to setting incentives can be represented by limiting the carbon price signal attached to GHG emissions. Political obstacles to pursuing certain emissions mitigation options can be introduced by placing restrictions on technology deployment. Distortions between the price and the marginal cost of abatement are captured by micro-economic behavioural parameters that introduce deviations from strict economic rationality. For example, actors in BLUE can exhibit differentiated sensitivities to changes in energy prices (demand elasticities), display different propensities for making decisions based purely on costs (market heterogeneity, intangible costs) and value the future differently (hurdle rates).

\subsection{Model operation}

BLUE is calibrated to UK national statistics to capture the UK energy system conditions for its starting 2010 base year, from where it projects energy demand, emissions, and technology adoption forward through time in response to actor decisions. The main exogenous drivers for the model include growth in end-use demands for energy, fossil fuel prices (for which the UK is largely a price-taker), and costs for energy demand and supply technologies (which again, are assumed to be driven largely by international developments in manufacturing and R\&D). The model documentation contains details of specific parameter settings. Exogenous fuel prices follow UK Government centrally projected trends, while cost reductions over time are captured for a number of transition technologies. Notably, these include power generation from onshore and offshore wind, solar photovoltaics (both grid-scale and building mounted), building heating with heat pumps, and mobility via electric drivetrain vehicles. In this version of the model, exogenous fuel price changes and changes to technology costs are assumed to reach a plateau in 2030 , the implications of which are discussed later in the paper (see Section 6.0).

Individual energy system actors in the energy supply and end-use sectors must make periodic decisions about capital stock replacement based on myopic expectations of levelised costs. This includes direct economic costs resulting from the capital purchases of assets, any taxes or subsidies, and the costs associated with equipment maintenance and the purchasing of fuels (if applicable). It also includes estimates of 
the intangible costs or benefits for different societal groups resulting from positive or negative effects on wellbeing resulting from the different choice that they make. These are typically estimated from stated preference surveys or willingness-to-pay studies, e.g. inconvenience or hassle factors can be interpreted as additional cost burdens [95], while it has been observed that customers will typically pay more for a trusted brand or one that they perceive will elevate their societal status when choosing between two functionally identical products $[96,97]$, indicating the presence of a non-cost benefit. Finally, to reflect the fact that not all decisions in the real world are made on the basis of strict economic rationality criteria, different model actors can have their behavioural settings altered to prioritise costs as a selection criterion to different degrees (this is handled through the heterogeneity parameter shown in Table 1).

\subsection{Model enhancements for this paper}

Whereas previous STET modelling work using BLUE has tried to explore shifting societal priorities and varying levels of climate policy action by government as exogenous model inputs (i.e. on/off switches that are external to the mathematical formulation), we have attempted here to endogenise parts of these critical parameters. This has presented various conceptual, methodological, and data-related challenges, which we reflect on later in Section 6.3. Key modifications to the latest BLUE model (BLUE 2.3) that distinguish it from previous publications are discussed below.

\subsubsection{Time horizon}

Previous versions of the model stepped through time to a 2050 end year. For this paper, we have extended the time horizon for BLUE out to the year 2070, as this could represent an important timeframe for the UK to achieve a "net-zero" GHG emissions position if equity-based burden sharing is the eventual outcome of the Paris Agreement process [53]. At the time of writing a "net-zero" target for the UK has yet to be legislated, with decarbonisation policy being conducted on the basis of the 10year old Climate Change Act [98].

\subsubsection{Government decision making}

We provide a summary description of government decision making in the model here, with references to the relevant supporting literature. A critical reflection on our particular conceptual framing for the role of the state and government-society relations in general appears later on in the paper (Section 6.2). A critical difference between the version of the model employed in this paper and prior versions is that in contrast to previous work, the Government is now represented as an active decision making actor which seeks to drive the transition towards climate targets. Our conceptual foundation lies in the idea that the Government can be represented as an 
actual autonomous actor pursuing its' own definition of national interests (a so-called state-centric approach [99]) rather than as the aggregate expression of the dynamics between multiple actors (industrial lobbies, social movements, political parties etc.). For the purposes of this paper, we take it as a given that the Government actor defines energy system decarbonisation as being in the national interest. The agency of the Government actor lies in its ability to intervene in the current socio-technical system by implementing both price-based and quantity-based policy interventions [100] towards this goal.

Past work has relied on the general concept of carbon permits [101] as a means of representing political action. In this paper, the Government retains the power to effect change across the entire energy system by setting a price on emissions, but its' role is expanded such that it can also consider penalties and incentives for specific technologies [102]. Market interventions by the government actor are scenario dependent and take the form of additional government support or regulation that is triggered when the market share of low carbon technologies reaches certain thresholds in the model (described later in Section 4.0). This means that government can intervene in markets to change the choice sets available to other actors in the model. Real world examples of market interventions by governments include direct support for energy efficiency programs, payments for microgeneration, mandating fuel switching (e.g. [103]) and executive decisions to phase out coal fired power (e.g. [104]) and fossil fuel cars (e.g. [105]) by certain future target dates.

The Government actor has wide ranging powers in the model but it is not represented as being omnipotent. Political science tells us that popular support (which can take more active or passive forms) is a key input into the political process and political decision-making in general [106], and that this takes the form of "cycles of interaction" between political actors and broader societal movements [107]. In the context of future transitions towards sustainability, the dynamic between "the rulers and the ruled" [108] is sometimes described as being governed by a form of "social contract" [109], or a "social mandate" [110]. The level of societal buy-in or alignment with broader socio-technical "strategic narratives" [111] such as the German Energiewende is sometimes described as being critical. It is argued that increased societal support is key to giving the State a "stronger mandate to act" [112] or a "strong social mandate for the energy transition" [110], particularly in the case of more radical transitions (e.g. [113]). We implement this feedback in our model by representing the Government actors' $\mathrm{CO}_{2}$ price-setting capabilities (specifically, the extent to which prices can be raised in each time-step) as being socially constrained. A challenge here is then how to represent the concept of societal support and understanding how much support is needed to trigger or enable different forms of authoritative decision making by government. Political theory acknowledges this as being difficult to operationalise and likely to be highly context dependent [106].

In this model, we employ the concept of a societal mandate for the energy transition and assume that ownership of low carbon technologies effectively creates a constituency of voters in favour of decarbonisation. This representation does have some limitations (which we explicitly address in Section 6.2) but aligns with the 
observation that policy interventions can only be sustained over time when they create a supportive interest group (see Patashnik [114] and Lockwood [115]).

In brief, government-society interactions in the model play out as follows: In each model year the government actor compares progress towards government climate targets and decides whether or not to maintain or raise $\mathrm{CO}_{2}$ pricing. If emissions are not falling, the government actor can decide to raise the $\mathrm{CO}_{2}$ price in the following year, but the extent to which this is possible is constrained by the overall societal mandate for the energy transition. If adoption of low carbon technologies is slow, then the government can only raise pricing by a small amount, but if it is rapid, then this implies a supportive electorate and increases in pricing can be relatively high.

For our analysis in this paper, we additionally impose an arbitrary maximum cap of $10 \%$ for a $\mathrm{CO}_{2}$ price rise in any given year, reflecting that this rate of change, if maintained, would result in a doubling approximately every 7 years (which is extremely rapid by any measure of systemic change). Finally, because political science tells us that backsliding on climate policy commitments, as well as weakening or abandoning long term targets are real possibilities $[115,116]$, we employ a mechanism whereby repeated failure to lower emissions over an arbitrary number of years (in this case 3 years in a row), results in a temporary setback for climate policy. This is represented by a temporary collapse in the carbon price of $10 \%$, which acts as a proxy for weakening government support.

\subsubsection{Societal groups and behaviour}

Decision making in consumer-driven end-use energy demand sectors such as residential housing and transport have been disaggregated into multiple social groups. While more detailed societal categories could be implemented in the BLUE model structure, for example, using demographic or income statistics, for this paper, we have followed a stylised Rogers diffusion curve that segments population into several groups which we term innovators, early adopters, early majority, late majority, and laggards [117]. We have then set up these different groups in the model to have different decision making parameters (see Table 1). We have employed the language of Rogers' work as it is remains most widely adopted and recognised theory on the diffusion of innovations. It is important however to note that our conceptual implementation of Rogers' groups is mainly focused on their appetite for risk, whereas Rogers' original definitions of the group structure also captured many additional elements. These include their social status, financial liquidity, degree of sociability, education level, the extent to which they have contact with and interact with the other groups (e.g. interaction between early majority and early adopters), and the degree to which they are "opinion leaders" [118] that can set and shape trends.

For the purposes of our paper, we characterise innovators as being the most forward looking category, with the longest term perspective on valuing the future and being the least sensitive to cost differentials between novel technologies and incumbent regime technologies. They are also configured to ignore the intangible costs 
associated with new and unfamiliar technologies (i.e. time costs, hassle factors [119]). We characterise laggards as being the most resistant to change, with short term perspectives on investments and a high sensitivity to costs, including intangible costs. All other groups are configured to be on a spectrum between these two extremes.

In Rogers' original work, the size of the different adopter groups is imagined as being fixed. In our representation of social groups, we represent the proportion of the population in each category as being able to change over time, enabling the model to explore long run shifts in societal preferences. Prominent in much of the transitions literature is the idea of imagining societal change from the "bottom-up" through social movements or actions by civil society, as opposed to state actors [120]. Central to this are ideas of "transformational change in societal values" [121], "deliberate transformation" of beliefs, values and worldviews [122,123], and a "worldwide shift in individual values towards sustainability" [108]. The main mechanism for representing the actions of non-state actors in the model are the investment behaviours displayed by social groups when they make choices about replacing capital assets. The idea of changing societal values is operationalised through changing the dominant investment behaviours for the social groups in the model, which enables it to be used for exploring the idea that consumer choices can be changed by means other than price signals [124].

The rate of societal change is linked to the societal mandate concept introduced in Section 3.3.2. We assume that a strong level of societal "buy-in" to the energy transition, evidenced by large numbers of voters purchasing low carbon technologies, may have the effect of changing attitudes and behaviours. We model this change in behaviour by creating a feedback loop between the societal mandate and the rate of change in population preferences away from the laggard group and towards the innovator end of the behavioural spectrum. As more low carbon technologies capture market share, the proportion of the population that is sensitive to the intangible costs associated with the selection of these previously new and unfamiliar technologies is reduced. Intangible costs in BLUE serve as a means of monetising the aspects of investment decisions that cannot be explained by direct financial costs (for a review of examples drawn from the buildings sector, see [125]). How these externalities are interpreted through the lens of economic theory is sometimes contested e.g. to what extent these extra barriers are the result of imperfect information or other mechanisms [126]. However, there is a wealth of evidence that increased societal exposure to new technologies creates a positive externality that acts to reduce or eliminate intangible costs, in a phenomenon sometimes called "learning by using" $[127,128]$. 
Table 1-Summary of behavioural parameters used for different societal groups

\begin{tabular}{|c|c|c|c|c|}
\hline $\begin{array}{l}\text { Societal } \\
\text { Group }\end{array}$ & $\begin{array}{c}\text { Initial } \\
\text { Population } \\
(\%)\end{array}$ & $\begin{array}{l}\text { Discount } \\
\text { Rate for } \\
\text { Decision } \\
\text { Making (\%) } \\
\end{array}$ & $\begin{array}{c}\text { Sensitivity to Costs } \\
\text { (Heterogeneity Parameter, v) }\end{array}$ & Intangible Costs \\
\hline Innovators & $2.5 \%$ & $3 \%$ & $\begin{array}{l}\text { 0-4 } \\
\text { Innovators do not react strongly to } \\
\text { prices and are instead principally } \\
\text { motivated by non-price factors }\end{array}$ & $\begin{array}{l}\text { Innovators ignore } \\
\text { intangible costs } \\
\text { entirely }\end{array}$ \\
\hline $\begin{array}{l}\text { Early } \\
\text { Adopters }\end{array}$ & $13.5 \%$ & $5 \%$ & \multirow{2}{*}{$\begin{array}{l}\text { 5-9 } \\
\text { Early Adopters and Early Majority } \\
\text { actors are price conscious but often } \\
\text { very large cost savings are required } \\
\text { before a total switch to new } \\
\text { technologies occurs }\end{array}$} & $\begin{array}{l}\text { Early Adopters perceive } \\
\text { half of the average } \\
\text { intangible costs }\end{array}$ \\
\hline $\begin{array}{l}\text { Early } \\
\text { Majority }\end{array}$ & $34 \%$ & $10 \%$ & & $\begin{array}{l}\text { The Early Majority } \\
\text { experience the average } \\
\text { level of intangible } \\
\text { costs }\end{array}$ \\
\hline $\begin{array}{l}\text { Late } \\
\text { Majority }\end{array}$ & $34 \%$ & $15 \%$ & $\begin{array}{l}10-19 \\
\text { Late Majority actors react strongly } \\
\text { to prices, but prices do not guide } \\
\text { all of their decisions }\end{array}$ & $\begin{array}{l}\text { The Late Majority are } \\
50 \% \text { more sensitive to } \\
\text { intangible costs }\end{array}$ \\
\hline Laggards & $16 \%$ & $20 \%$ & $\begin{array}{l}10-50 \\
\text { Laggards will choose the least cost } \\
\text { option almost every time, even if } \\
\text { the savings are very small }\end{array}$ & $\begin{array}{l}\text { Laggards perceive } \\
\text { intangible costs to be } \\
\text { twice as large as the } \\
\text { average person }\end{array}$ \\
\hline
\end{tabular}

\subsubsection{Technologies}

A number of additional disruptive niche technologies have been added to the model, for societal groups to choose from in various market segments. These include domestic microgeneration, non-motorised transport, and highly thermally efficient buildings.

\subsection{Thought experiment}

\subsection{Rationale}

As alluded to in the introduction of this paper, the issue of who leads and who follows in future energy transitions is not straightforward to conceptualise or assess. In this section, we conduct a series of thought experiments [29] to understand how different configurations of the energy system might emerge under different political and societal conditions, represented in the BLUE model. The intention behind this exercise is primarily methodological in nature. The scenario analysis is exploratory in 
character [36], and so is neither intended to be comprehensive, nor a reflection on what is plausible or desirable.

Philosophically the intention behind conducting a thought experiment is to explore relationships between the driving forces in the model to explore how they affect the evolution of the critical model parameters of interest (in this case, energy demand, emissions, and technology diffusion) as a means of gaining further insights into the mechanics of the real world system $[129,130]$. Such an exercise pushes the boundaries of whole system STET modelling, and we can also use the outputs to infer critical insights about the relative importance of social action and government policy in terms of their ability to shape future energy transitions. While the specific case study here is focused on the United Kingdom, which has a unique energy system and sociopolitical character, the broad insights generated are applicable to other contexts.

\subsection{Exploratory dimensions}

We present four different transition scenarios to unpick the leader-follower question, arranged as a simple $2 \times 2$ scenario matrix depicted in Figure 2 . These are based on the concept of there being a single lead actor that initiates the transition, and a counterpart supporting actor. For the purposes of our thought experiment, we consider that either government or society can be the lead actor. We also consider that the supporting actor can follow the direction of travel indicated by the lead, or resist. This of course is an abstraction of the multiple interaction pathways that might exist for driving systemic change, but serves as a starting point for discussion. The possible combinations of actor settings therefore include:

- Government leads, society follows (GL-SF)

- Government leads, society resists (GL-SR)

- Society leads, government follows (SL-GF)

- Society leads government resists (SL-GR) 
Figure 2 - Scenario matrix for model-based thought experiment

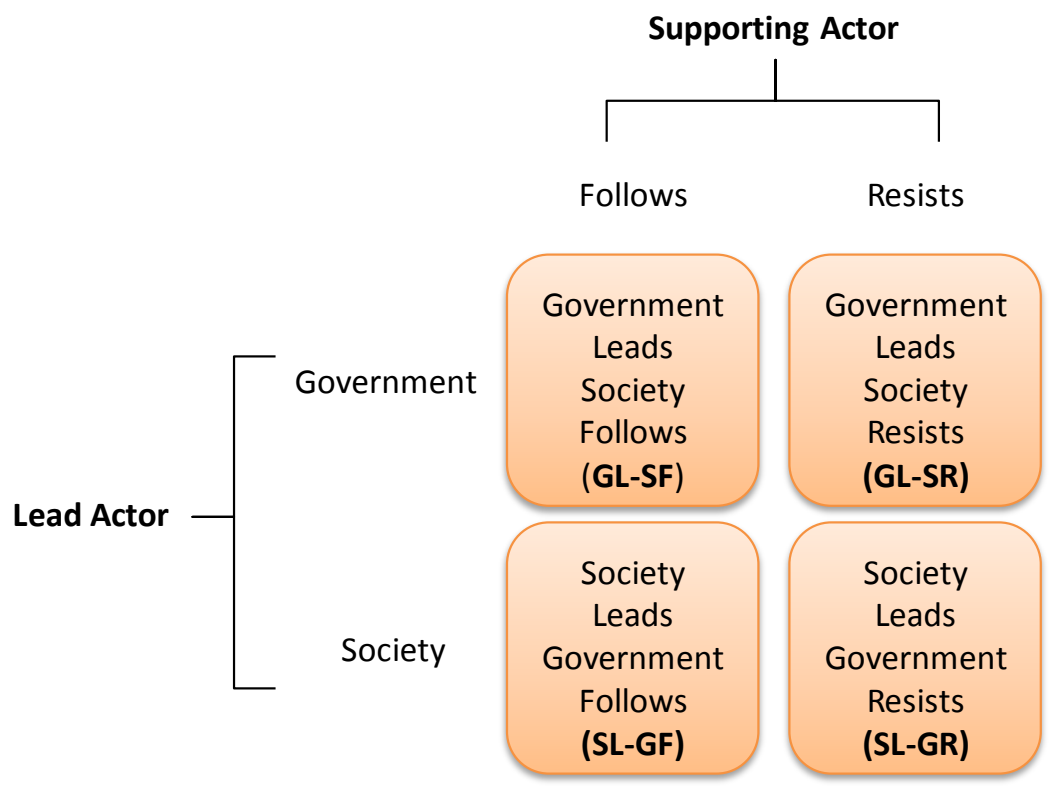

In each case, leading implies a different set of near-term activities that result in sociopolitical inertia being overcome. If government leads the transition, this entails spending political and financial capital to change the choice sets available to the rest of the system, removing or reducing the appeal of polluting options and getting new low carbon alternatives onto the table. If society leads, this change implies a shift in attitudes and purchasing behaviour such that deliberate choices are made to value low carbon technologies over their fossil fuelled counterparts. The issue of what elements in the real world system are represented by "society" is addressed later in discussion (see Section 6.2.1).

\subsection{Experimental settings}

Table 2 below discusses the different model settings applied in each transition scenario.

Table 2 - Experimental settings applied in each transition scenario

\begin{tabular}{|c|c|c|c|}
\hline Scenario & Overview & Government & Society \\
\hline $\begin{array}{l}\text { Government } \\
\text { Leads } \\
\text { Society } \\
\text { Follows } \\
\text { (GL-SF) }\end{array}$ & $\begin{array}{l}\text { Illustrates very strong } \\
\text { government intervention } \\
\text { in markets including bans } \\
\text { on polluting technologies } \\
\text { when these are still in the } \\
\text { majority, with society } \\
\text { changing over time in } \\
\text { response to new norms } \\
\text { that emerge. }\end{array}$ & $\begin{array}{l}\text { Carbon pricing at rates that are socially } \\
\text { constrained. } \\
\text { Strong and persistent support for new } \\
\text { technologies. Heavy subsidies } \\
\text { implemented ( } 50 \% \text { of costs) for electric } \\
\text { vehicles, electric heat pumps, near zero } \\
\text { heating buildings, and residential } \\
\text { microgeneration as long as these have } \\
\text { less than an } 80 \% \text { market share. }\end{array}$ & $\begin{array}{l}\text { Societal preferences } \\
\text { (\% population in each } \\
\text { societal group) are } \\
\text { allowed to shift over } \\
\text { time, at a rate linked } \\
\text { to adoption of new } \\
\text { innovations, as } \\
\text { described in Section } \\
3 \cdot 3 \cdot 3 \text {. }\end{array}$ \\
\hline
\end{tabular}




\begin{tabular}{|c|c|c|c|}
\hline $\begin{array}{l}\text { Government } \\
\text { Leads } \\
\text { Society } \\
\text { Resists } \\
\text { (GL-SR) }\end{array}$ & $\begin{array}{l}\text { Shows the effects of } \\
\text { strong government } \\
\text { intervention in the } \\
\text { existing socio-technical } \\
\text { regime (identical to GL- } \\
\text { SF), but with society } \\
\text { imagined as being static } \\
\text { in terms of how } \\
\text { preferences change. }\end{array}$ & $\begin{array}{l}\text { Action to remove polluting } \\
\text { technologies when they are still in the } \\
\text { mainstream. Fossil-fuel technologies in } \\
\text { end-use sectors (fossil fuelled vehicles } \\
\text { and gas boilers) are banned outright if } \\
\text { they fall below an } 80 \% \text { market share. } \\
\text { New unabated coal and gas fired power } \\
\text { plant are banned. } \\
\text { Forced retirement of fossil fuel power } \\
\text { generation by } 2025 \text {. }\end{array}$ & $\begin{array}{l}\text { Societal preferences } \\
\text { remain at initial levels } \\
\text { (no change in } \\
\text { population } \\
\text { preferences, ०\%). }\end{array}$ \\
\hline $\begin{array}{l}\text { Society } \\
\text { Leads } \\
\text { Government } \\
\text { Follows } \\
\text { (SL-GF) }\end{array}$ & $\begin{array}{l}\text { Depicts an } \\
\text { unprecedented societal } \\
\text { shift in attitudes and } \\
\text { behaviours, with some } \\
\text { moderate government } \\
\text { support for the transition } \\
\text { (weaker than the GL } \\
\text { cases). }\end{array}$ & $\begin{array}{l}\text { Carbon pricing at rates that are socially } \\
\text { constrained. } \\
\text { Support for new technologies to } \\
\text { establish a foothold in the market. } \\
\text { Heavy subsidies implemented (50\% of } \\
\text { costs) for electric vehicles, electric heat } \\
\text { pumps, near zero heating buildings, } \\
\text { and residential microgeneration as long } \\
\text { as these have less than an } 30 \% \text { market } \\
\text { share. } \\
\text { Polluting technologies start to be } \\
\text { managed out of the system only when } \\
\text { their numbers fall to relatively low } \\
\text { levels in the overall system mix. Fossil- } \\
\text { fuel technologies in end-use sectors } \\
\text { (fossil fuelled vehicles and gas boilers) } \\
\text { are banned outright if they fall below } \\
\text { an } 20 \% \text { market share. } \\
\text { New unabated coal and gas fired power } \\
\text { plant are banned, with existing legacy } \\
\text { plant finishing out their service lives. }\end{array}$ & \multirow[t]{2}{*}{$\begin{array}{l}\text { A rapid shift in societal } \\
\text { preferences such that } \\
\text { nearly all of the } \\
\text { population is in what is } \\
\text { viewed in } 2010 \text { as the } \\
\text { innovator category by } \\
\text { 2050: making long } \\
\text { term decisions on } \\
\text { valuing the future, } \\
\text { valuing non-cost } \\
\text { factors when making } \\
\text { technology selections, } \\
\text { and ignoring what are } \\
\text { viewed in 2010 as } \\
\text { intangible costs } \\
\text { (hassle factors, } \\
\text { unfamiliarity with new } \\
\text { technologies etc.) }\end{array}$} \\
\hline $\begin{array}{l}\text { Society } \\
\text { Leads } \\
\text { Government } \\
\text { Resists } \\
\text { (SL-GR) }\end{array}$ & $\begin{array}{l}\text { Demonstrates the } \\
\text { outcome of a future that } \\
\text { sees massive shift in } \\
\text { societal preferences } \\
\text { (same as SL-GF), but } \\
\text { with little corresponding } \\
\text { government action to } \\
\text { support the transition. }\end{array}$ & $\begin{array}{l}\text { Carbon pricing at rates that are socially } \\
\text { constrained. } \\
\text { No subsidises for clean technologies. } \\
\text { No market interventions to ban } \\
\text { polluting technologies. }\end{array}$ & \\
\hline
\end{tabular}

\subsection{Results}

We assess the rate of technological transitions in three major sectors, passenger road transport, residential heating, and power supply, while also exploring the ability of the whole energy system to decarbonise in line with climate targets. Additionally, we 
show the level of carbon taxation achieved in each transition, which is an important marker for the interaction between society and government, as well as the distribution of the population amongst societal groups with different behavioural parameters, which enables discussion of how social change is currently operationalised in the model.

\subsection{Carbon tax}

Figure 3 shows the profile of carbon taxation in each of the four transition scenarios. Section 3.3.2 and Table 2 explain how the government actor can raise or lower the $\mathrm{CO}_{2}$ price based on its own goals and the evolution of the social mandate it faces. The first three scenarios (GL-SF, GL-SR, SL-GF) all see sustained increases in the $\mathrm{CO}_{2}$ price from 2010 to 2050, starting at around $22 \mathrm{f} /$ ton and ending at $100 \mathrm{f} /$ ton. The scenario with the heaviest government intervention in markets (GL-SF), then goes on to see the price increase rapidly to around $750 \mathrm{f} /$ ton by 2070 , while the other scenarios see increases to around $300 \mathrm{f} / \mathrm{ton}$, less than half of this level. These results are function of the dynamic feedback that occurs between government and societal actors.

GL-SF has the highest final $\mathrm{CO}_{2}$ price of all four scenarios because of the strong positive feedback loops that occur in the model. Government action to heavily subsidise new technologies leads to their rapid adoption by some groups, growing the size of the user base for low carbon technologies and the overall societal mandate for the transition. This strengthened societal mandate, in turn, drives a shift in consumer preferences towards the innovator end of the spectrum, further accelerating the rate of new technology adoption. It also enables the government to push the rate of $\mathrm{CO}_{2}$ tax increases on polluting technologies harder, which incentivises the shift to nonfossil fuel technologies still further. The lower final $\mathrm{CO}_{2}$ price in GL-SR can be attributed to the lack of change in societal preferences in this scenario, which leads to lower levels of new technology adoption, and a lower societal mandate for change. The reduced societal mandate in GL-SR (as compared to GL-SF) makes it more difficult for the government to ratchet up $\mathrm{CO}_{2}$ pricing across the model time horizon. The lower final $\mathrm{CO}_{2}$ price in SL-GF is also linked to a lower societal mandate for the transition and less headroom for government to increase $\mathrm{CO}_{2}$ prices, but in this case, this is the result of weaker government support for market intervention rather than a failure to shift consumer preferences. Finally, the SL-GR scenario sees a very weak carbon price trajectory which collapses shortly after 2040 and then never recovers across the modelled time horizon above $50 \mathrm{f} /$ ton. In this scenario, the lack of any specific government actions to support low carbon technologies or disincentivise fossil fuel technologies leads to an ineffectual carbon pricing policy that is periodically abandoned. 
Figure $3-$ Carbon tax applied in different transition scenarios (average of $n=500$ simulations)
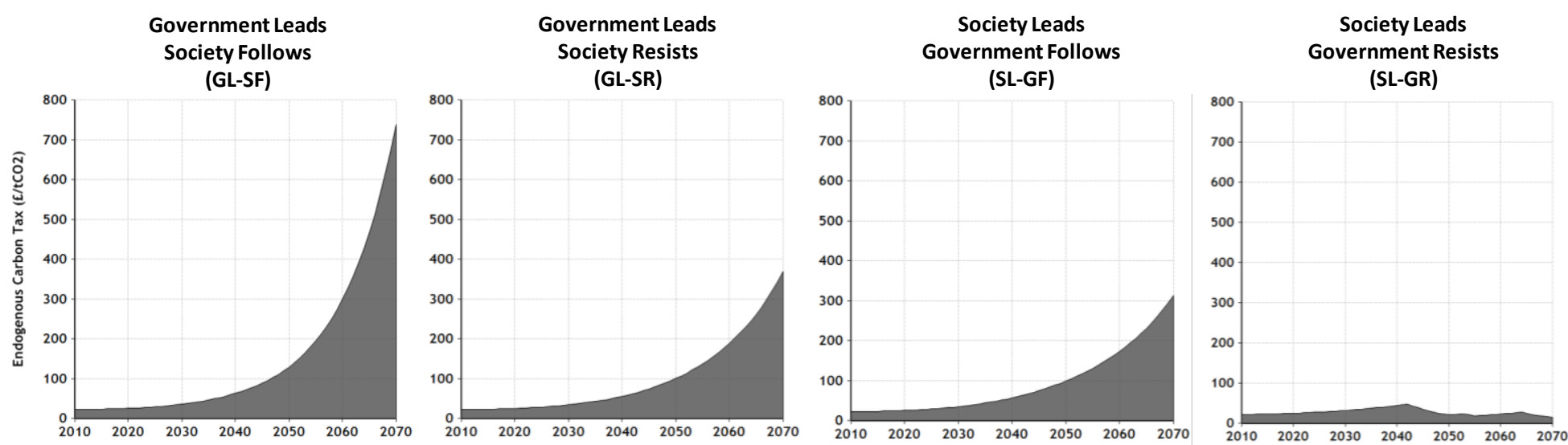

\subsection{Societal groups}

Figure 4 illustrates the distribution of the population into different societal groups and how these change in each modelled transition. In GL-SF, the increasing adoption of low carbon technologies creates a feedback loop that results in changes to societal preferences over time (see Section 3.3.3). There is a large shift towards the innovator category by 2050 and nearly all of the population is operating in this mode of decision making by 2070. In GL-SR, we explore a scenario where no change in societal preferences occurs. Finally, in the Society Leads scenarios of SL-GF and SL-GR we explore an extremely rapid societal shift that is exogenously imposed, and which results in nearly $100 \%$ of the population joining the innovator category by 2050 .

Figure 4 - Societal group distribution in different transition scenarios (average of $\mathrm{n}=500$ simulations)
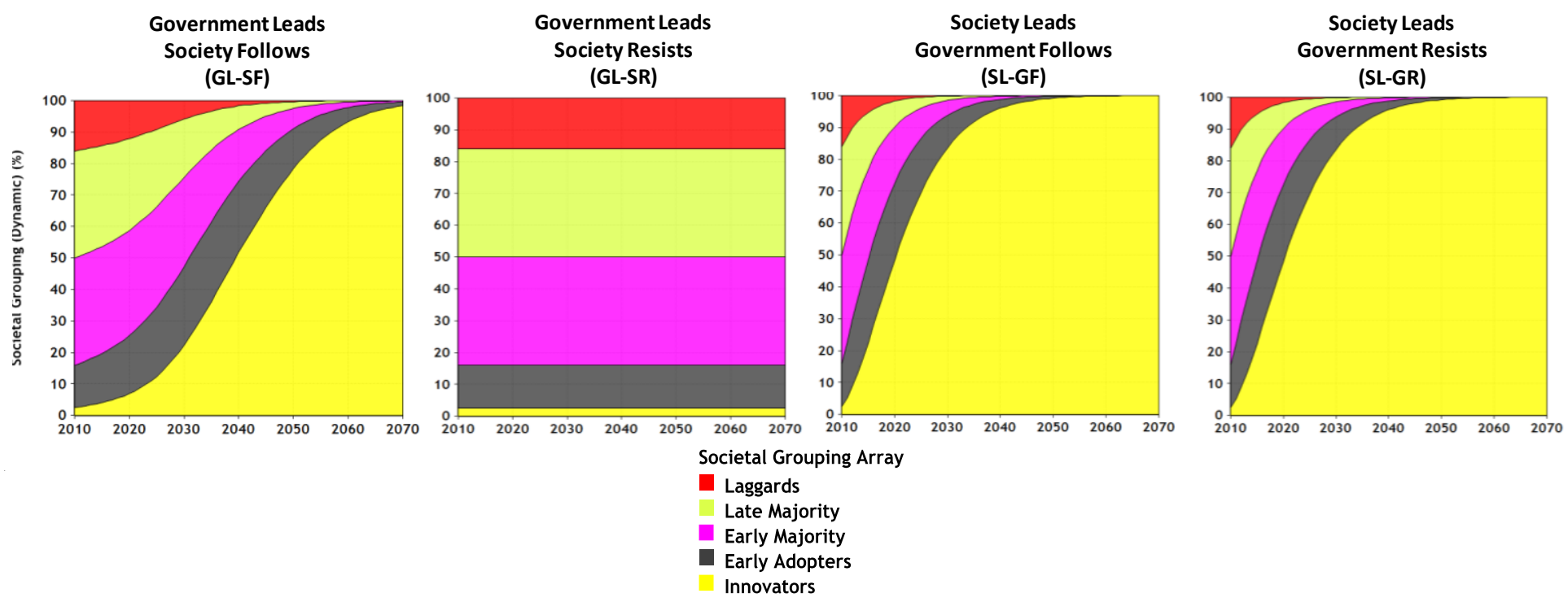


\subsection{Power sector}

Figure 5 illustrates how the transition scenarios unfold in the power sector through the model time horizon. The introduction of carbon pricing in all four scenarios together with the falling costs of renewable energy means that the power sector sees significant transitions away from fossil fuels in all cases. Coal power (in grey) is either forced off the system entirely through policy action (GL-SF, GL-SR, SL-GF) or is outcompeted by the alternatives (SL-GR) by the 2030s. Scenarios with early policy action to remove all unabated fossil fuels from electricity production (GL-SF, GL-SR, SL-GF) also see natural gas without carbon capture and storage (in orange) disappear from the system, but this technology is found to retain significant market share if it is not regulated against (as in SL-GR). SL-GR does feature a carbon tax, but the price is low and inconsistent, never reaching levels that are high enough to force gas off the system (see Section 5.1). The void left by fossil fuels in all cases is filled by varying amounts of nuclear power (red), solar power ( 2 shades of yellow) wind power ( 2 shades of blue), natural gas with carbon capture and storage (CCS) or bioenergy CCS ( 2 shades of green). CCS technology is assumed to be made available in the early 20305 .

The influence of social change on the power sector can be seen in the uptake of solar microgeneration (light yellow) in those scenarios where society follows (GL-SF) or where society leads the transition (SL-GF, SL-GR). In these cases, the changes in societal preferences and decision making (see Section 5.2) lead to solar microgeneration capturing very large shares of the installed power grid capacity. This can be contrasted against the outcome in the scenario where society resists and societal preferences do not change (GL-SR), which sees microgeneration playing only a minimal role in the overall generation mix.

Figure 5 - Power sector transition scenarios (average of $\mathrm{n}=500$ simulations)
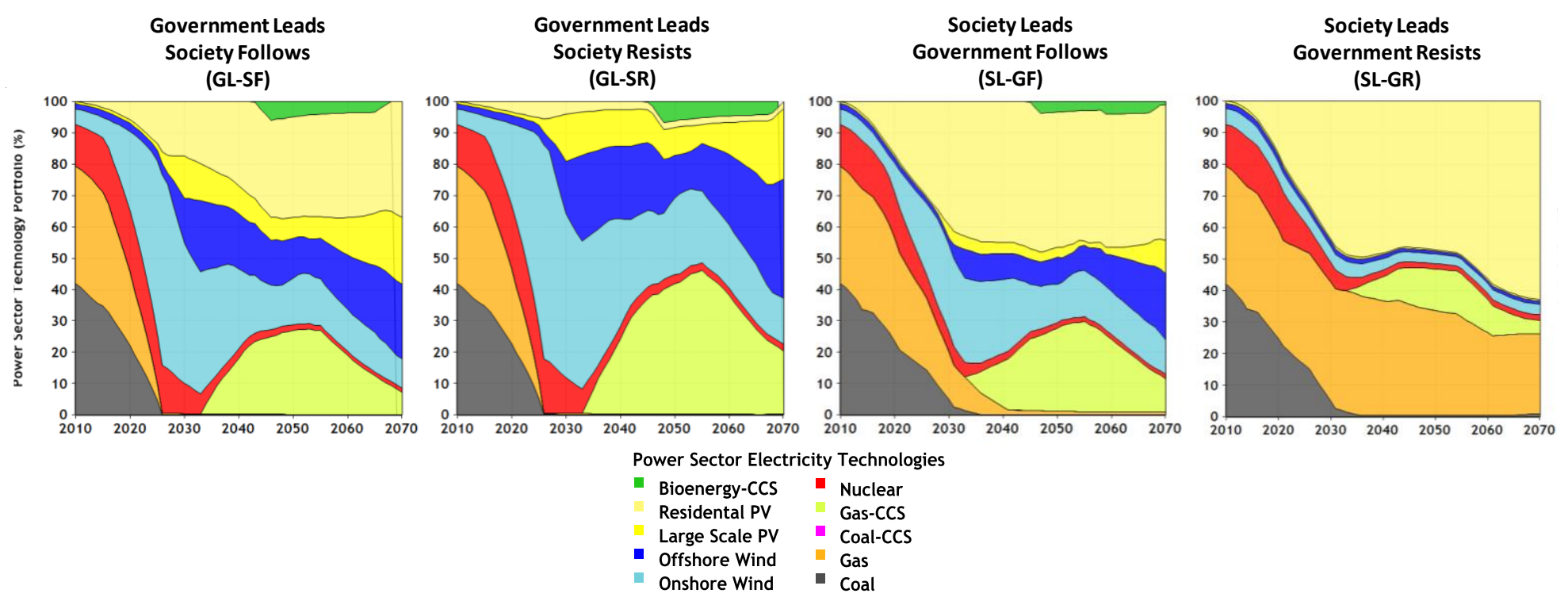


\subsection{Residential heating}

Figure 6 illustrates the transition scenarios in the residential heating sector. Natural gas boilers are indicated in grey, heat pumps in orange, direct electric heating in yellow, and the uptake of near-zero heating homes (which displace energy that would otherwise be used for heat supply) in bright green. The largest transition is found in the Government Leads, Society Follows (GL-SF) scenario which features the heaviest government intervention and a shift in societal preferences. In this case, a step change in the rate of adoption of electrical alternatives to gas boilers can be seen around 2040, where a ban on new gas boilers is implemented as ownership falls to $80 \%$ of market share.

The power of government action alone is shown to be limited however, if societal preferences do not change, as in the Government Leads, Society Resists (GL-SR) scenario. This scenario features the same generous subsidies for low carbon heating ( $50 \%$ of costs) and a rising carbon price as the previously discussed GL-SF scenario, but the lack of change in societal preferences means that these measures do not prove to be enough to overcome the price advantage of incumbent technologies. Both of the societally led scenarios (SL-GF, SL-GR) see an increasing adoption of alternative heating solutions over time. Compared to the government led transition scenarios, there is actually a larger shift in the earlier years of the transition. However, in the absence of strong government intervention (natural gas boilers for example, are never regulated against in these two examples) neither scenario experiences large shifts away from fossil fuel heating by the end of the modelled time horizon.

Figure 6 - Residential heating transition scenarios (average of $n=500$ simulations)
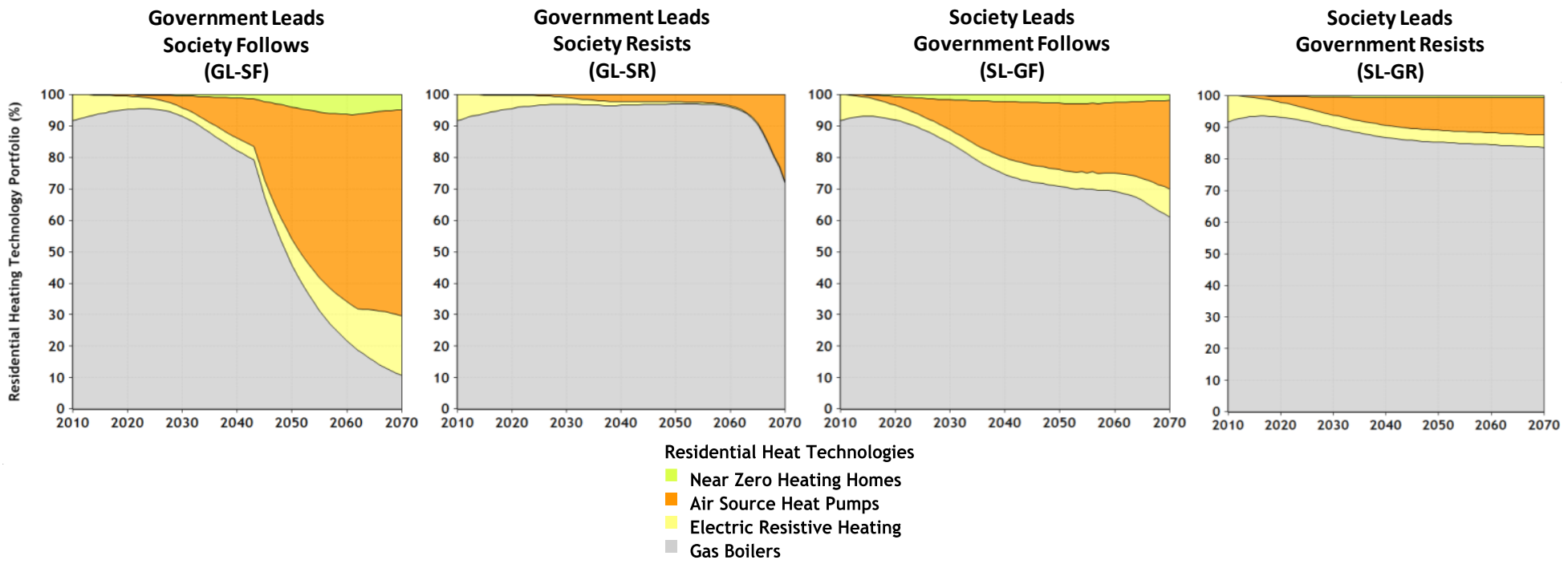

\subsection{Passenger road transport}

Figure 7 shows transition scenarios for passenger road transport. Incumbent fossil fuel vehicles are indicated in grey, with electrical vehicles in yellow and non-motorised 
transport (NMT) options like cycling and walking in purple. The jagged lines on the charts for the NMT option are the result of oscillatory behaviour whereby the model comes up repeatedly against a deployment constraint, calibrated to the maximum number of passenger kilometres ( $\mathrm{pkm}$ ) via NMT, which is set to correspond to a level of cycling infrastructure penetration similar to that of the Netherlands (one of Europe's most cycling-friendly countries). All four scenarios actually see a similar uptake of non-motorised transport by the end of the model time horizon.

The government led scenarios (GL-SF, GL-SR) see the highest levels of adoption of electric vehicles. A step change in the levels of adoption in both scenarios is observed around 2030 which is where government intervention is used to ban new fossil fuel vehicles. This has the effect of causing a very high penetration of electric vehicles by the end of the time horizon, even in the scenario where societal preferences do not change (GL-SR). This because, following government action, even the laggard societal group has no alternative but to purchase electric vehicles when their existing fossil-fuel vehicles are retired. The societally led scenarios (SL-GF, SL-GR) also see significant electric vehicle penetration, although the weaker (SL-GF) or non-existent (SL-GR) levels of government intervention do not close the gap in costs between low carbon and fossil fuel vehicles quite enough to see a total transformation of the sector.

Figure 7 - Passenger road transport transition scenarios (average of $n=500$ simulations)
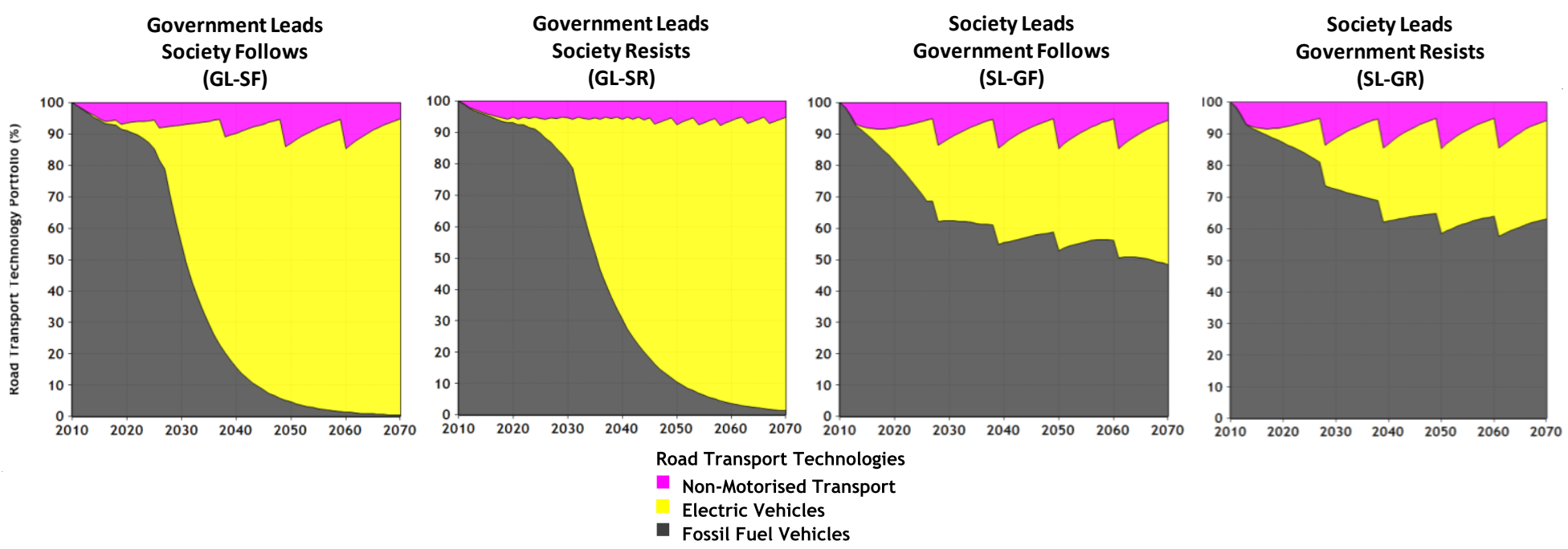

\subsection{Climate targets}

Figure 8 depicts a series of probability density functions for the level of emissions reductions achieved in each model run across $n=500$ simulations. The distribution of outcomes depicted is the result of the use of Monte-Carlo sampling [131] of inputs in order to capture a degree of uncertainty in numerous parameters such as the costs and performance of different technologies or in behavioural responses [132]. The green shaded areas indicate climate targets for 2050 and for 2070 . The UK's statutory climate objective is an 80\% reduction in GHG emissions by 2050 (relative to 1990 
levels) [98], but as BLUE only accounts for $\mathrm{CO}_{2}$ emissions we use a $90 \%$ reduction in $\mathrm{CO}_{2}$ as our deep decarbonisation target following the established approach applied in similar studies [52]. We also indicate a $100 \% \mathrm{CO}_{2}$ reduction target for 2070 , which is indicative of the level of decarbonisation effort that would be commensurate with a "net-zero" emissions target for the UK in line with the Paris Agreement [53]. At the time of publication, the UK Government has indicated a desire to move towards setting a domestic net-zero target, but no decisions have yet been taken about the time horizon for this to be achieved.

Across the range of scenarios, the range of possible outcomes is generally wider in 2070 than in 2050. Out of the four scenarios explored here, the two featuring the heaviest government intervention (GL-SF, GL-SR) emerge as achieving the deepest emissions reductions, although neither option (as modelled) strikes the target areas within the range of their probabilistic outcomes. The societally led scenarios (SL-GF, SL-GR) also achieve significant reductions in emissions relative to 1990 levels but these are lower than those achieved in the government-led scenarios and accordingly do not come close to the climate targets discussed above.

Figure 8 -Emissions reductions against climate targets for the year 2050 and for the year 2070 in different transition scenarios ( $n=500$ simulations)
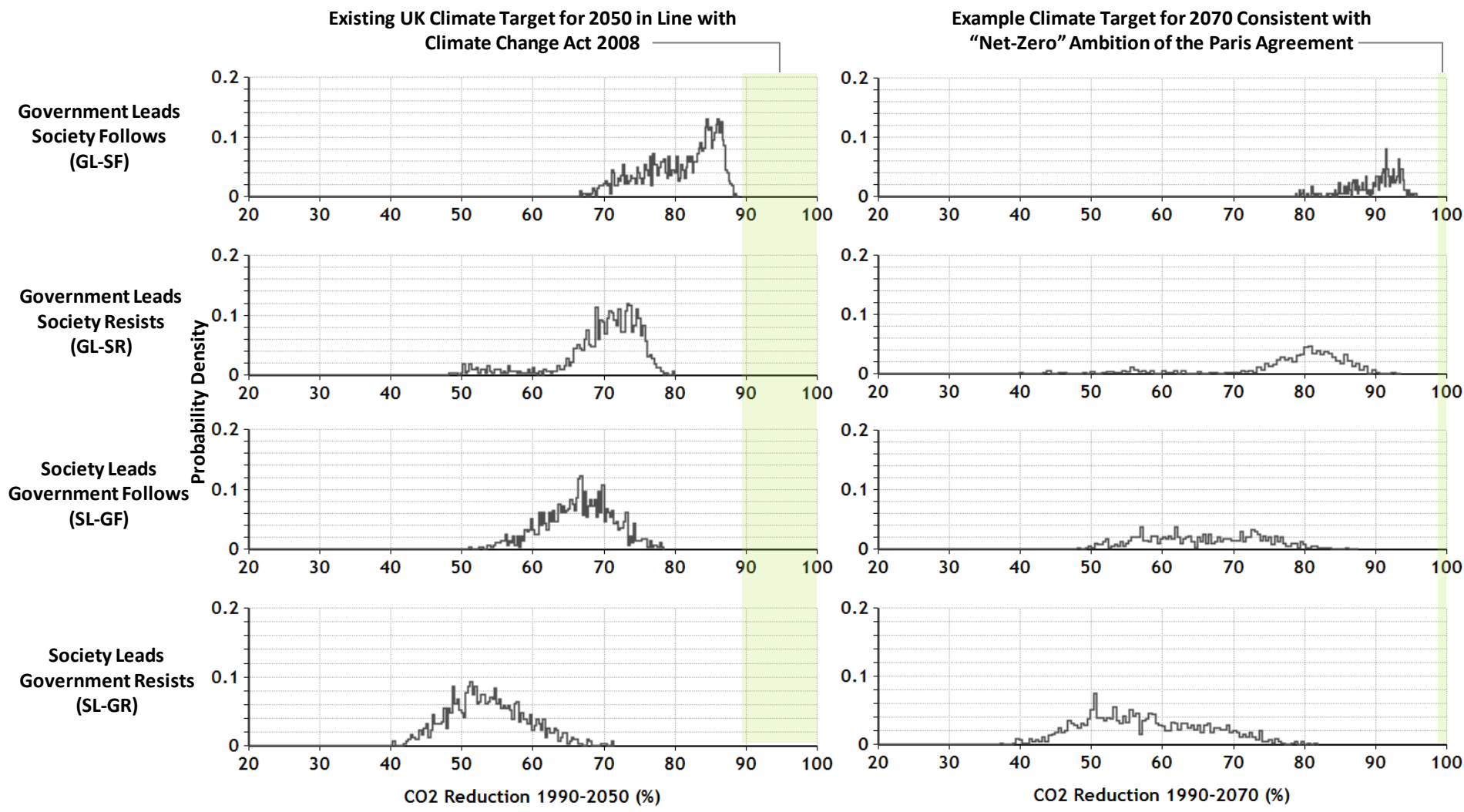


\subsection{Discussion}

\subsection{General insights from results}

The framing question for our thought experiment was: Should government or society lead the energy transition? The results show that both government-led and societallydriven transition scenarios hold the potential to deeply decarbonise the energy system. However, the most successful efforts at deep decarbonisation appear to be achieved when the initial momentum created by the leading party is then maintained when the counterpart follows i.e. GL-SF performs better than GL-SR, and SL-GF performs better than SL-GR. As modelled, it can be seen that the influence of the government actor appears more powerful than the societal actors, with GL-SF and GL-SR both decarbonising further than SL-GF and SL-GR. This is primarily because in our experiment the government actor is able to make transformative decisions about what choices were available to other actors across the entire energy system through regulation. The prohibition of new fossil fuel technologies in the residential heating and passenger road transport sectors relatively early on in the transition appear to be key to this increased level of decarbonisation in the government-led scenarios.

Another key finding from the analysis is that inertia in the system resulting from the long lifetimes of capital assets (power stations, building equipment, vehicles, etc.) and the limited pace of societal change meant that none of the model runs explored in this paper were able to achieve the level of climate ambition implied by the UK's existing 2050 climate law or a hypothetical revised target in line with the international Paris Agreement aspiration for net-zero energy systems. Those scenarios which came close used highly interventionist, almost draconian measures to take polluting options off the table even when these were mainstream choices favoured by the majority of the population. For example, measures included banning new sales of fossil fuel vehicles and fossil fuel heating devices when they still comprised the majority of the market in their respective sectors, and the forced retirement of coal and gas fired power stations well ahead of their natural economic lifetimes.

This finding should be viewed in light of several important input assumptions (originally highlighted in Section 3.2). The model runs presented in this paper assume that full technological maturity is reached by 2030 for several critical transition technologies. So while their modelled costs do fall rapidly at compound rates of $1-3 \%$ per year for several decades, they are assumed to reach a plateau relatively early in the total model time horizon. It is conceivable that future costs could reduce faster than our default assumptions, that they could continue to fall further beyond our assumed dates for technological maturity, or that they could even experience radical and discontinuous shifts in costs over time. Another important assumption to note is that radical changes to end-use energy service demands that might result from future changes to economic structure and lifestyles (such as mobility and settlement patterns), are not yet comprehensively explored. The task of expanding the range of the analysis across these important dimensions lies slightly outside of the scope of ambition for this paper, but the implications for meeting climate targets of 
challenging our default assumptions in this regard could certainly be valuable avenues of investigation to explore in future work.

\subsection{Critical reflection on limitations and areas for future work}

\subsubsection{Representation of society}

In this analysis, we have represented society as a stylised unipolar Rogers curve [117] with laggards at one end and innovators at the other, but societal groups could be represented as heterogeneous constellations of actors that exhibit differentiated preferences according to patterns of lifestyle choices, age, demographics, income, voting behaviour etc. From a quantitative modelling perspective, this would need to be computationally tractable and be grounded in real world social statistics. There is also scope for STET analysis to explore additional critical actors, with an obvious candidate for inclusion in future work being the financial sector, as advocated by Pollitt and Mercure [133]. Alongside changes to individual behaviours, future shifts in corporate culture and the decisions of firms could also be important $[134,135]$. Another area of improvement for future work is the interactions between different representative agents, which is not captured in the current analysis. In reality, social influence effects [136] and the actions of "transformational individuals" [137] who inspire others to collective action appear to be important in driving changes to values and behaviour. An additional layer of complexity is also introduced when such trends are considered to evolve dynamically over time [138].

The idea of society "leading" is only narrowly operationalised in this paper as selfdirected changes to investment decision making. This offers only a narrow conception of what is potentially a complex transformative process that could develop along multiple pathways (for an example typology of social change from different groups, see Dahle [139]). The co-ordination mechanism that leads to different elements in society coming together to change the status quo is not depicted. Indeed, it is not certain that a strong and consistent societal shift in values and worldviews would emerge from the messy process of consensus-building and alliance formation amongst disparate non-State actors such as political interest groups, lobbying groups, and societal movements. While there is evidence that some changes towards more sustainable cultural values and behaviours is already underway in the present day $[140,141]$, it is far from clear whether or how these early trends might translate to new purchasing behaviours or whether they would lead to the kind of profound "culture-shift" [142] or "awakening moment" [143] that precipitates fundamental societal change in much of the sustainability literature.

\subsubsection{Representation of government}

In their work on meta-theoretical approaches to analysing transitins, Cherp et al. [99] note that the "conceptualization of the state" is often contested. In this paper, we have taken a state-centric approach to representing government with a single representative agent, but we could equally have taken a so-called state-structural approach. Government could equally be represented in future STET models by a 
range of actors representing different government branches (i.e. executive, judicial, legislative), departments (housing, transport etc.) or as different political parties vying for power (for interesting models of coalition forming, see $[144,145]$ ).

The issue of political consistency across time could be expanded significantly further. Here, we have represented government as a monolithic entity that makes incremental decisions according to consistent rules, in an approach which might be termed by political scientists as an incrementalist framing [146]. However, actor roles and relationships in future transitions may actually change over time [147], and with them the "political opportunity structure" for implementing pro-transition policies. A seminal overview of general theories of the energy policy making process by Grossman [116] highlights multiple streams, punctuated equilibrium, and advocacy coalition frameworks as leading concepts for future work to explore.

The types of powers and level of agency attributed to the government actor in our model could also be refined in future work. In this model version we have illustrated the effect of an economy wide $\mathrm{CO}_{2}$ price-signal. At present, the UK does not have domestic policies for specifically pricing $\mathrm{CO}_{2}$ although consumers are charged for energy produced from fossil fuels in the form of the Climate Change Levy (CCL) [148], which has been argued to amount to an "implicit carbon tax" [149]. While the CCL does not cover all sectors (notably, road transport fuels are absent and industrial emissions are charged through other means such as the European Emissions Trading Scheme), it illustrates the kind of mechanism that could be expanded in future, especially given the long time horizon for the model (to 2070). There is no theoretical reason why a carbon tax could not be introduced for consumers in the same way as Valued Added Tax (VAT) is already collected using existing administrative and enforcement institutions [150].

\subsubsection{Representation of government-society relations}

Finally, the co-evolving relationship between political and societal actors and how they exert varying degrees of power over the pace and direction of the future energy transition is perhaps the most interesting area for future investigation. While few political scientists might disagree with the idea that government power in a democracy is influenced by the electorate and that this relationship is a core factor influencing political decision making, operationalising this link in a formal model is not straightforward [151]. In this paper, we have used the concept of the societal mandate to explore the society-government relationship, based on the idea that ownership of low carbon technologies implies a political constituency in favour of system change $[114,115]$. But the relationship between purchasing behaviour and support for government policies is of course potentially much more complex and nuanced than this. For example, it does not follow automatically that purchasers of electric vehicles would accept regulation against polluting vehicles, although many may do so. Political support is also clearly a bi-directional phenomenon [106], with the government able to generate increased "social acceptance" through information campaigns or other measures $[110,121]$. 


\subsection{Towards improving the value of STET modelling for policy}

A number of caveats, which we address in discussion, apply to the general findings of the thought experiments depicted in this paper. This means that while we can draw useful inferences about the relative importance of societal change (i.e. what happens if it is faster, slower, or no change occurs) and political action (i.e. what happens if stronger or weaker actions in different sectors occur), we cannot state with confidence that deployment levels for different technologies or the levels of emissions reductions achieved in the model are representative of the real world. However, what this analysis does achieve is a valuable demonstration of the critical importance of societal and political elements in radically shaping future energy transitions and how they might be operationalised in quantitative energy models.

Two decades of effort to implement the low-carbon energy transition has shown analysts and policymakers how complex the political and social elements of such an economy-wide non-marginal change actually are. The idea that both top-down and bottom-up elements are vital for successful transitions is by no means new [152], but most energy models continue to be built to explore top-down changes and technological diffusion in the absence of societal innovation. We argue that this risks unwittingly perpetuating the illusion that top-down steering by government alone can bring about the energy transition (a perspective termed "cockpit-ism" by Hajer et al. [153]). This status quo can, and should be contested. Developing models that capture complex societal and political processes alongside technological and environmental ones is far from straightforward, but potentially offers new avenues for learning, stakeholder engagement, and the co-design of shared futures. Energy modellers must rise to this challenge.

\section{References}

[1] L. Clarke, K. Jiang, K. Akimoto, M. Babiker, G. Blanford, K. Fisher-Vanden, J.-C. Hourcade, V. Krey, E. Kriegler, A. Löschel, D. McCollum, S. Paltsev, S. Rose, P.R. Shukla, M. Tavoni, B.C.C. van der Zwaan, D.P. van Vuuren, Assessing Transformation Pathways, in: O. Edenhofer, R. Pichs-Madruga, Y. Sokona, E. Farahani, S. Kadner, K. Seyboth, A. Adler, I. Baum, S. Brunner, P. Eickemeier, B. Kriemann, J. Savolainen, S. Schlömer, V. Stechow, T. Zwickel, J.C. Minx (Eds.), Clim. Chang. 2014 Mitig. Clim. Chang. Contrib. Work. Gr. III to Fifth Assess. Rep. Intergov. Panel Clim. Chang., Cambridge University Press, Cambridge, United Kingdom and New York, NY, USA, 2014: pp. 413-510. https://www.ipcc.ch/pdf/assessmentreport/ar5/wg3/ipcc_wg3_ar5_chapter6.pdf.

[2] UNFCCC, Adoption of the Paris Agreement: Proposal by the President: Draft decision -/CP.21, United Nations Framework Convention on Climate Change (UNFCCC), 2015. http://unfccc.int/resource/docs/2015/cop21/eng/logro1.pdf.

[3] J. Morgan, E. Northrop, Will the Paris Agreement accelerate the pace of 
change?, Wiley Interdiscip. Rev. Clim. Chang. 8 (2017) e471.

doi:10.1002/wCC.471.

[4] C. Wilson, A. Grübler, Lessons from the history of technological change for clean energy scenarios and policies, Nat. Resour. Forum. 35 (2011) 165-184. doi:10.1111/j.1477-8947.2011.01386.x.

[5] B.K. Sovacool, How long will it take? Conceptualizing the temporal dynamics of energy transitions, Energy Res. Soc. Sci. 13 (2016) 202-215.

doi:10.1016/j.erss.2015.12.020.

[6] B.K. Sovacool, F.W. Geels, Further reflections on the temporality of energy transitions: A response to critics, Energy Res. Soc. Sci. 22 (2016) 232-237. doi:10.1016/j.erss.2016.08.013.

[7] A. Grubler, C. Wilson, G. Nemet, Apples, oranges, and consistent comparisons of the temporal dynamics of energy transitions, Energy Res. Soc. Sci. 22 (2016) 18-25. doi:10.1016/j.erss.2016.08.015.

[8] V. Smil, Examining energy transitions: A dozen insights based on performance, Energy Res. Soc. Sci. 22 (2016) 194-197. doi:10.1016/j.erss.2016.08.017.

[9] F. Kern, K.S. Rogge, The pace of governed energy transitions: Agency, international dynamics and the global Paris agreement accelerating decarbonisation processes?, Energy Res. Soc. Sci. 22 (2016) 13-17. doi:10.1016/j.erss.2016.08.016.

[10] J. Markard, R. Raven, B. Truffer, Sustainability transitions: An emerging field of research and its prospects, Res. Policy. 41 (2012) 955-967. doi:10.1016/j.respol.2012.02.013.

[11] E.J.L. Chappin, A. Ligtvoet, Transition and transformation: A bibliometric analysis of two scientific networks researching socio-technical change, Renew. Sustain. Energy Rev. 30 (2014) 715-723. doi:10.1016/j.rser.2013.11.013.

[12] R. Fouquet, P.J.G. Pearson, A Thousand Years of Energy Use in the United Kingdom, Energy J. 19 (1998). doi:10.5547/ISSNo195-6574-EJ-Vol19-No4-1.

[13] G. Verbong, F.W. Geels, The ongoing energy transition: Lessons from a sociotechnical, multi-level analysis of the Dutch electricity system (1960-2004), Energy Policy. 35 (2007) 1025-1037. doi:10.1016/j.enpol.2006.02.010.

[14] P.J.G. Pearson, T.J. Foxon, A low carbon industrial revolution? Insights and challenges from past technological and economic transformations, Energy Policy. 50 (2012) 117-127. doi:10.1016/j.enpol.2012.07.061.

[15] R.F. Hirsh, C.F. Jones, History's contributions to energy research and policy, Energy Res. Soc. Sci. 1 (2014) 106-111. doi:10.1016/j.erss.2014.02.010.

[16] C.A. Miller, A. Iles, C.F. Jones, The Social Dimensions of Energy Transitions, Sci. Cult. (Lond). 22 (2013) 135-148. doi:10.1080/09505431.2013.786989. 
[17] G. Luderer, C. Bertram, K. Calvin, E. De Cian, E. Kriegler, Implications of weak near-term climate policies on long-term mitigation pathways, Clim. Change. (2013). doi:10.1007/s10584-013-0899-9.

[18] G.J. Blanford, E. Kriegler, M. Tavoni, Harmonization vs. fragmentation: overview of climate policy scenarios in EMF27, Clim. Change. 123 (2014) 383396. doi:10.1007/s10584-013-0951-9.

[19] N. Hughes, Towards improving the relevance of scenarios for public policy questions: A proposed methodological framework for policy relevant low carbon scenarios, Technol. Forecast. Soc. Change. 80 (2013) 687-698. doi:10.1016/j.techfore.2012.07.009.

[20] N. Hughes, N. Strachan, Methodological review of UK and international low carbon scenarios, Energy Policy. 38 (2010) 6056-6065. doi:10.1016/j.enpol.2010.05.061.

[21] S. Sarkki, J. Niemela, R. Tinch, S. van den Hove, A. Watt, J. Young, Balancing credibility, relevance and legitimacy: A critical assessment of trade-offs in science-policy interfaces, Sci. Public Policy. 41 (2014) 194-206. doi:10.1093/scipol/scto46.

[22] J.-F. Mercure, H. Pollitt, A.M. Bassi, J.E. Viñuales, N.R. Edwards, Modelling complex systems of heterogeneous agents to better design sustainability transitions policy, Glob. Environ. Chang. 37 (2016) 102-115. doi:10.1016/j.gloenvcha.2016.02.003.

[23] M.J. Grubb, M. Ha-Duong, J.-C. Hourcade, Influence of socioeconomic inertia and uncertainty on optimal CO2-emission abatement, Nature. 390 (1997) 270273. doi:10.1038/36825.

[24] S.J. Davis, K. Caldeira, H.D. Matthews, Future $\mathrm{CO}_{2}$ Emissions and Climate Change from Existing Energy Infrastructure, Science (80-. ). 329 (2010) 13301333. doi:10.1126/science.1188566.

[25] W.B. Arthur, Competing Technologies, Increasing Returns, and Lock-In by Historical Events, Econ. J. 99 (1989) 116. doi:10.2307/2234208.

[26] G.C. Unruh, Understanding carbon lock-in, Energy Policy. 28 (2000) 817-830. doi:10.1016/S0301-4215(00)00070-7.

[27] T.J. Foxon, G.P. Hammond, P.J.G. Pearson, Developing transition pathways for a low carbon electricity system in the UK, Technol. Forecast. Soc. Change. 77 (2010) 1203-1213. doi:10.1016/j.techfore.2010.04.002.

[28] T.J. Foxon, Transition pathways for a UK low carbon electricity future, Energy Policy. 52 (2013) 10-24. doi:10.1016/j.enpol.2012.04.001.

[29] S. Häggqvist, A Model for Thought Experiments, Can. J. Philos. 39 (2009) 5576. doi:10.1353/cjp.0.0040. 
[30] T. Bruckner, I.A. Bashmakov, Y. Mulugetta, H. Chum, A. De la Vega Navarro, J. Edmonds, A. Faaij, B. Fungtammasan, A. Garg, E. Hertwich, D. Honnery, D.G. Infield, M. Kainuma, S. Khennas, S. Kim, H. Bashir Nimir, K. Riahi, N. Strachan, R. Wiser, X. Zhang, Energy Systems, in: O. Edenhofer, R. Pichs-Madruga, Y. Sokona, E. Farahani, S. Kadner, K. Seyboth, A. Adler, I. Baum, S. Brunner, P. Eickemeier, B. Kriemann, J. Savolainen, S. Schlömer, C. von Stechow, T. Zwickel, J.C. Minx (Eds.), Clim. Chang. 2014 Mitig. Clim. Chang. Contrib. Work. Gr. III to Fifth Assess. Rep. Intergov. Panel Clim. Chang., Cambridge University Press, Cambridge, United Kingdom and New York, NY, USA, 2014: p. 139. http://ipcc.ch/pdf/assessment-report/ar5/wg3/ipcc_wg3_ar5_chapter7.pdf.

[31] J. Rogelj, A. Popp, K. V. Calvin, G. Luderer, J. Emmerling, D. Gernaat, S. Fujimori, J. Strefler, T. Hasegawa, G. Marangoni, V. Krey, E. Kriegler, K. Riahi, D.P. van Vuuren, J. Doelman, L. Drouet, J. Edmonds, O. Fricko, M. Harmsen, P. Havlík, F. Humpenöder, E. Stehfest, M. Tavoni, Scenarios towards limiting global mean temperature increase below $1.5^{\circ} \mathrm{C}$, Nat. Clim. Chang. 8 (2018) 325-332. doi:10.1038/s41558-018-0091-3.

[32] G. Luderer, Z. Vrontisi, C. Bertram, O.Y. Edelenbosch, R.C. Pietzcker, J. Rogelj, H.S. De Boer, L. Drouet, J. Emmerling, O. Fricko, S. Fujimori, P. Havlík, G. Iyer, K. Keramidas, A. Kitous, M. Pehl, V. Krey, K. Riahi, B. Saveyn, M. Tavoni, D.P. Van Vuuren, E. Kriegler, Residual fossil $\mathrm{CO}_{2}$ emissions in $1.5^{-2}{ }^{\circ} \mathrm{C}$ pathways, Nat. Clim. Chang. 8 (2018) 626-633. doi:10.1038/s41558-018-0198-6.

[33] S. Pye, C. McGlade, C. Bataille, G. Anandarajah, A. Denis-Ryan, V. Potashnikov, Exploring national decarbonization pathways and global energy trade flows: a multi-scale analysis, Clim. Policy. 16 (2016) S92-S109. doi:10.1080/14693062.2016.1179619.

[34] S. Pye, C. Bataille, Improving deep decarbonization modelling capacity for developed and developing country contexts, Clim. Policy. 16 (2016) S27-S46. doi:10.1080/14693062.2016.1173004.

[35] J.-C. Hourcade, M. Jaccard, C. Bataille, F. Ghersi, Hybrid Modeling: New Answers to Old Challenges Introduction to the Special Issue of The Energy Journal, Energy J. SI2006 (2006). doi:10.5547/ISSN0195-6574-EJ-VolSI2006NoSl2-1.

[36] L. Börjeson, M. Höjer, K.-H. Dreborg, T. Ekvall, G. Finnveden, Scenario types and techniques: Towards a user's guide, Futures. 38 (2006) 723-739. doi:10.1016/j.futures.2005.12.002.

[37] J.B. Robinson, Futures under glass, Futures. 22 (1990) 820-842. doi:10.1016/0016-3287(90)90018-D.

[38] J.F. DeCarolis, H. Daly, P.E. Dodds, I. Keppo, F. Li, W. McDowall, S. Pye, N. Strachan, E. Trutnevyte, W. Usher, M. Winning, S. Yeh, M. Zeyringer, Formalizing best practice for energy system optimization modelling, Appl. Energy. 194 (2017) 184-198. doi:10.1016/j.apenergy.2017.03.001. 
[39] J. Forrester, Counterintuitive behavior of social systems, Technol. Forecast. Soc. Change. 3 (1971) 1-22. doi:10.1016/S0040-1625(71)80001-X.

[40] J.M. Epstein, R.L. Axtell, Growing artificial societies: Social science from the bottom up, Comput. Math. with Appl. 33 (1997) 127. doi:10.1016/So8981221(97)82923-9.

[41] K. Safarzyńska, J.C.J.M. van den Bergh, An evolutionary model of energy transitions with interactive innovation-selection dynamics, J. Evol. Econ. 23 (2013) 271-293. doi:10.1007/s00191-012-0298-9.

[42] K. Safarzyńska, J.C.J.M. van den Bergh, Integrated crisis-energy policy: Macroevolutionary modelling of technology, finance and energy interactions, Technol. Forecast. Soc. Change. (2016). doi:10.1016/j.techfore.2016.07.033.

[43] M. Borup, N. Brown, K. Konrad, H. Van Lente, The sociology of expectations in science and technology, Technol. Anal. Strateg. Manag. 18 (2006) 285-298. doi:10.1080/09537320600777002.

[44] Y. Garb, S. Pulver, S.D. VanDeveer, Scenarios in society, society in scenarios: toward a social scientific analysis of storyline-driven environmental modeling, Environ. Res. Lett. 3 (2008) 045015. doi:10.1088/1748-9326/3/4/045015.

[45] M. Nilsson, L.J. Nilsson, R. Hildingsson, J. Stripple, P.O. Eikeland, The missing link: Bringing institutions and politics into energy future studies, Futures. 43 (2011) 1117-1128. doi:10.1016/j.futures.2011.07.010.

[46] J. Rogelj, G. Luderer, R.C. Pietzcker, E. Kriegler, M. Schaeffer, V. Krey, K. Riahi, Energy system transformations for limiting end-of-century warming to below $1.5^{\circ} \mathrm{C}$, Nat. Clim. Chang. 5 (2015) 519-527. doi:10.1038/nclimate2572.

[47] A. Grubler, C. Wilson, N. Bento, B. Boza-Kiss, V. Krey, D.L. McCollum, N.D. Rao, K. Riahi, J. Rogelj, S. De Stercke, J. Cullen, S. Frank, O. Fricko, F. Guo, M. Gidden, P. Havlík, D. Huppmann, G. Kiesewetter, P. Rafaj, W. Schoepp, H. Valin, A low energy demand scenario for meeting the $1.5^{\circ} \mathrm{C}$ target and sustainable development goals without negative emission technologies, Nat. Energy. 3 (2018) 515-527. doi:10.1038/s41560-018-0172-6.

[48] T. Napp, D. Bernie, R. Thomas, J. Lowe, A. Hawkes, A. Gambhir, Exploring the Feasibility of Low-Carbon Scenarios Using Historical Energy Transitions Analysis, Energies. 10 (2017) 116. doi:10.339o/en10010116.

[49] W. McDowall, Validating hydrogen transitions with lessons from the past, Technol. Forecast. Soc. Change. (n.d.).

[50] A. Marcucci, H. Turton, Induced technological change in moderate and fragmented climate change mitigation regimes, Technol. Forecast. Soc. Change. 90 (2015) 230-242. doi:10.1016/j.techfore.2013.10.027.

[51] M. Schaeffer, L. Gohar, E. Kriegler, J. Lowe, K. Riahi, D. van Vuuren, Mid- and long-term climate projections for fragmented and delayed-action scenarios, 
Technol. Forecast. Soc. Change. 90 (2015) 257-268.

doi:10.1016/j.techfore.2013.09.013.

[52] N. Strachan, W. Usher, Failure to achieve stringent carbon reduction targets in a second-best policy world, Clim. Change. 113 (2011) 121-139.

doi:10.1007/s10584-011-0267-6.

[53] S. Pye, F.G.N. Li, J. Price, B. Fais, Achieving net-zero emissions through the reframing of UK national targets in the post-Paris Agreement era, Nat. Energy. 2 (2017) 17-24. doi:10.1038/nenergy.2017.24.

[54] K.L. Ebi, S. Hallegatte, T. Kram, N.W. Arnell, T.R. Carter, J. Edmonds, E. Kriegler, R. Mathur, B.C. O’Neill, K. Riahi, H. Winkler, D.P. Van Vuuren, T. Zwickel, A new scenario framework for climate change research: background, process, and future directions, Clim. Change. 122 (2014) 363-372. doi:10.1007/s10584-013-0912-3.

[55] D.L. McCollum, C. Wilson, H. Pettifor, K. Ramea, V. Krey, K. Riahi, C. Bertram, Z. Lin, O.Y. Edelenbosch, S. Fujisawa, Improving the behavioral realism of global integrated assessment models: An application to consumers' vehicle choices, Transp. Res. Part D Transp. Environ. 55 (2017) 322-342. doi:10.1016/j.trd.2016.04.003.

[56] H. Pettifor, C. Wilson, D. McCollum, O.Y. Edelenbosch, Modelling social influence and cultural variation in global low-carbon vehicle transitions, Glob. Environ. Chang. 47 (2017) 76-87. doi:10.1016/j.gloenvcha.2017.09.008.

[57] K. Ramea, D.S. Bunch, C. Yang, S. Yeh, J.M. Ogden, Integration of behavioral effects from vehicle choice models into long-term energy systems optimization models, Energy Econ. 74 (2018) 663-676. doi:10.1016/j.eneco.2018.06.028.

[58] A.P. Kirman, Whom or What Does the Representative Individual Represent?, J. Econ. Perspect. 6 (1992) 117-136. doi:10.1257/jep.6.2.117.

[59] J.-F. Mercure, F. Knobloch, L. Paroussos, S. Scrieciu, R. Lewney, Modelling Innovation and the Macroeconomics of Low-Carbon Transitions: Theory, Perspectives and Practical Use, Cambridge Centre for Environment, Energy and Natural Resource Governance, University of Cambridge, Cambridge, UK, 2017. http://www.ceenrg.landecon.cam.ac.uk/working-paper-files/wp14.

[6o] T. Balint, F. Lamperti, A. Mandel, M. Napoletano, A. Roventini, A. Sapio, Complexity and the Economics of Climate Change: A Survey and a Look Forward, Ecol. Econ. 138 (2017) 252-265. doi:10.1016/j.ecolecon.2017.03.032.

[61] J. Halbe, D.E. Reusser, G. Holtz, M. Haasnoot, A. Stosius, W. Avenhaus, J.H. Kwakkel, Lessons for model use in transition research: A survey and comparison with other research areas, Environ. Innov. Soc. Transitions. (2014). doi:10.1016/j.eist.2014.10.001.

[62] G. Holtz, F. Alkemade, F. de Haan, J. Köhler, E. Trutnevyte, T. Luthe, J. Halbe, G. Papachristos, E.J.L. Chappin, J. Kwakkel, S. Ruutu, Prospects of modelling 
societal transitions: Position paper of an emerging community, Environ. Innov. Soc. Transitions. (2015). doi:10.1016/j.eist.2015.05.006.

[63] A.C.G. Cooper, Building physics into the social : Enhancing the policy impact of energy studies and energy social science research, Energy Res. Soc. Sci. 26 (2017) 80-86. doi:10.1016/j.erss.2017.01.013.

[64] F.W. Geels, J. Schot, Typology of sociotechnical transition pathways, Res. Policy. 36 (2007) 399-417. doi:10.1016/j.respol.2007.01.003.

[65] T.J. Foxon, A coevolutionary framework for analysing a transition to a sustainable low carbon economy, Ecol. Econ. 70 (2011) 2258-2267. doi:10.1016/j.ecolecon.2011.07.014.

[66] K. Safarzyńska, K. Frenken, J.C.J.M. van den Bergh, Evolutionary theorizing and modeling of sustainability transitions, Res. Policy. 41 (2012) 1011-1024. doi:10.1016/j.respol.2011.10.014.

[67] C.S.E. Bale, L. Varga, T.J. Foxon, Energy and complexity: New ways forward, Appl. Energy. 138 (2015) 150-159. doi:10.1016/j.apenergy.2014.10.057.

[68] J.H. Kwakkel, M. Haasnoot, W.E. Walker, Developing dynamic adaptive policy pathways: a computer-assisted approach for developing adaptive strategies for a deeply uncertain world, Clim. Change. 132 (2015) 373-386.

doi:10.1007/s10584-014-1210-4.

[69] F.G.N. Li, E. Trutnevyte, N. Strachan, A review of socio-technical energy transition (STET) models, Technol. Forecast. Soc. Change. 100 (2015) 290-305. doi:10.1016/j.techfore.2015.07.017.

[70] F.G.N. Li, N. Strachan, Modelling energy transitions for climate targets under landscape and actor inertia, Environ. Innov. Soc. Transitions. 24 (2017) 106129. doi:10.1016/j.eist.2016.08.002.

[71] W. McDowall, F.W. Geels, Ten challenges for computer models in transitions research: Commentary on Holtz et al., Environ. Innov. Soc. Transitions. (2016). doi:10.1016/j.eist.2016.07.001.

[72] B. Turnheim, F. Berkhout, F. Geels, A. Hof, A. McMeekin, B. Nykvist, D. van Vuuren, Evaluating sustainability transitions pathways: Bridging analytical approaches to address governance challenges, Glob. Environ. Chang. 35 (2015) 239-253. doi:10.1016/j.gloenvcha.2015.08.010.

[73] P. Fortes, A. Alvarenga, J. Seixas, S. Rodrigues, Long-term energy scenarios: Bridging the gap between socio-economic storylines and energy modeling, Technol. Forecast. Soc. Change. 91 (2015) 161-178. doi:10.1016/j.techfore.2014.02.006.

[74] E.A. Moallemi, L. Aye, F.J. de Haan, J.M. Webb, A dual narrative-modelling approach for evaluating socio-technical transitions in electricity sectors, J. Clean. Prod. 162 (2017) 1210-1224. doi:10.1016/j.jclepro.2017.06.118. 
[75] G. Papachristos, A system dynamics model of socio-technical regime transitions, Environ. Innov. Soc. Transitions. 1 (2011) 202-233. doi:10.1016/j.eist.2011.10.001.

[76] A. Genus, A.-M. Coles, Rethinking the multi-level perspective of technological transitions, Res. Policy. 37 (2008) 1436-1445. doi:10.1016/j.respol.2008.05.006.

[77] F.W. Geels, The multi-level perspective on sustainability transitions: Responses to seven criticisms, Environ. Innov. Soc. Transitions. 1 (2011) 24-40. doi:10.1016/j.eist.2011.02.002.

[78] D. Cash, W.C. Clark, F. Alcock, N.M. Dickson, N. Eckley, J. Jäger, Salience, Credibility, Legitimacy and Boundaries: Linking Research, Assessment and Decision Making, John F. Kennedy School of Government, Harvard University, Cambridge, MA, USA, 2002.

https://papers.ssrn.com/sol3/papers.cfm?abstract_id=372280.

[79] D.W. Cash, W.C. Clark, F. Alcock, N.M. Dickson, N. Eckley, D.H. Guston, J. Jager, R.B. Mitchell, Knowledge systems for sustainable development, Proc. Natl. Acad. Sci. 100 (2003) 8086-8091. doi:10.1073/pnas.1231332100.

[8o] R.J. Lempert, S.W. Popper, S.C. Bankes, Shaping the Next One Hundred Years: New Methods for Quantitative, Long-Term Policy Analysis. RAND report MR1626., RAND Corporation, RAND Corporation, The RAND Pardee Center, Santa Monica, CA, USA, 2003.

https://www.rand.org/content/dam/rand/pubs/monograph_reports/2007/MR16 26.pdf.

[81] P.G. Taylor, P. Upham, W. McDowall, D. Christopherson, Energy model, boundary object and societal lens: 35 years of the MARKAL model in the UK, Energy Res. Soc. Sci. 4 (2014) 32-41. doi:10.1016/j.erss.2014.08.007.

[82] A. Voinov, F. Bousquet, Modelling with stakeholders, Environ. Model. Softw. 25 (2010) 1268-1281. doi:10.1016/j.envsoft.2010.03.007.

[83] J.D. Sterman, T. Fiddaman, T. Franck, A. Jones, S. McCauley, P. Rice, E. Sawin, L. Siegel, Management flight simulators to support climate negotiations, Environ. Model. Softw. 44 (2013) 122-135. doi:10.1016/j.envsoft.2012.06.004.

[84] S. Malekpour, F.J. de Haan, R.R. Brown, Marrying Exploratory Modelling to Strategic Planning: Towards Participatory Model Use, in: 2oth Int. Congr. Model. Simul., Adelaide, Australia, 2013. www.mssanz.org.au/modsimzo13.

[85] M. Hulme, S. Dessai, Predicting, deciding, learning: can one evaluate the 'success' of national climate scenarios?, Environ. Res. Lett. 3 (2008) 045013. doi:10.1088/1748-9326/3/4/045013.

[86] E. Trutnevyte, The allure of energy visions: Are some visions better than others?, Energy Strateg. Rev. 2 (2014) 211-219. doi:10.1016/j.esr.2013.10.001.

[87] J. Smith, R. Butler, R.J. Day, A.H. Goodbody, D.H. Llewellyn, M. Rohse, B.T. 
Smith, R.A. Tyszczuk, J. Udall, N.M. Whyte, Gathering around stories:

Interdisciplinary experiments in support of energy system transitions, Energy Res. Soc. Sci. 31 (2017) 284-294. doi:10.1016/j.erss.2017.06.026.

[88] K. Hasselmann, D. V. Kovalevsky, Simulating animal spirits in actor-based environmental models, Environ. Model. Softw. 44 (2013) 10-24. doi:10.1016/j.envsoft.2012.04.007.

[89] F.G.N. Li, Actors behaving badly: Exploring the modelling of non-optimal behaviour in energy transitions, Energy Strateg. Rev. 15 (2017) 57-71. doi:10.1016/j.esr.2017.01.002.

[90] M. Horne, M. Jaccard, K. Tiedemann, Improving behavioral realism in hybrid energy-economy models using discrete choice studies of personal transportation decisions, Energy Econ. 27 (2005) 59-77. doi:10.1016/j.eneco.2004.11.003.

[91] P. Capros, L. Paroussos, P. Fragkos, S. Tsani, B. Boitier, F. Wagner, S. Busch, G. Resch, M. Blesl, J. Bollen, Description of models and scenarios used to assess European decarbonisation pathways, Energy Strateg. Rev. 2 (2014) 220-230. doi:10.1016/j.esr.2013.12.008.

[92] L. Mantzos, N.A. Matei, M. Rózsai, P. Russ, A.S. Ramirez, POTEnCIA: A new EU-wide energy sector model, in: 2017 14th Int. Conf. Eur. Energy Mark., IEEE, 2017: pp. 1-5. doi:10.1109/EEM.2017.7982028.

[93] I. Staub-Kaminski, A. Zimmer, M. Jakob, R. Marschinski, Climate policy in practice: a typology of obstacles and implications for integrated assessment modeling, Clim. Chang. Econ. 05 (2014) 1440004. doi:10.1142/S2010007814400041.

[94] C. Wilson, H. Dowlatabadi, Models of Decision Making and Residential Energy Use, Annu. Rev. Environ. Resour. 32 (2007) 169-203. doi:10.1146/annurev.energy.32.053006.141137.

[95] R. Scarpa, K. Willis, Willingness-to-pay for renewable energy: Primary and discretionary choice of British households' for micro-generation technologies, Energy Econ. 32 (2010) 129-136. doi:10.1016/j.eneco.2009.06.004.

[96] L. Neij, L. Mundaca, E. Moukhametshina, Choice-decision determinants for the (non) adoption of energy efficiency technologies in households, in: Eceee 2009 Summer Study (European Counc. an Energy Effic. Econ. Act! Innov. Deliv. Reducing Energy Demand Sustain., 2009: pp. 687-695. http://www.eceee.org/library/conference_proceedings/eceee_Summer_Studie s/2009/Panel_3/3.285.

[97] J. Axsen, K.S. Kurani, Social Influence, Consumer Behavior, and Low-Carbon Energy Transitions, Annu. Rev. Environ. Resour. 37 (2012) 311-340. doi:10.1146/annurev-environ-062111-145049.

[98] HM Government, Climate Change Act 2008, HMSO, London, UK, 2008. 
http://www.legislation.gov.uk/ukpga/2008/27/pdfs/ukpga_20080027_en.pdf.

[99] A. Cherp, V. Vinichenko, J. Jewell, E. Brutschin, B. Sovacool, Integrating techno-economic, socio-technical and political perspectives on national energy transitions: A meta-theoretical framework, Energy Res. Soc. Sci. 37 (2018) 175190. doi:10.1016/j.erss.2017.09.015.

[100] M.L. Weitzman, Prices vs. Quantities, Rev. Econ. Stud. 41 (1974) 477-491. http://www.jstor.org/stable/2296698.

[101] S. Polborn, The Political Economy of Carbon Securities and Environmental Policy, SSRN Electron. J. (2010) 31. doi:10.2139/ssrn.1662427.

[102] D.A. Robalino, R.J. Lempert, Carrots and sticks for new technology: Abating greenhouse gas emissions in a heterogeneous and uncertain world, Integr. Assess. 1 (2000) 1-19. doi:10.1023/A:1019159210781.

[103] S. Arapostathis, A. Carlsson-Hyslop, P.J.G. Pearson, J. Thornton, M. Gradillas, S. Laczay, S. Wallis, Governing transitions: Cases and insights from two periods in the history of the UK gas industry, Energy Policy. 52 (2013) 25-44. doi:10.1016/j.enpol.2012.08.016.

[104] BEIS, The Clean Growth Strategy: Leading the Way to a Low Carbon Future, UK Department for Business Energy and Industrial Strategy (BEIS), London, UK, 2017. https://www.gov.uk/government/publications/clean-growthstrategy.

[105] Ministère de la Transition écologique et solidaire, Plan Climat: 1 Planète, 1 Plan, Ministère de la Transition écologique et solidaire, Paris, France, 2017. https://www.ecologique-solidaire.gouv.fr/sites/default/files/2017.07.06 - Plan Climat_o.pdf.

[106] D. Easton, An Approach to the Analysis of Political Systems, World Polit. 9 (1957) 383-400. doi:10.2307/2008920.

[107] J. Meadowcroft, Engaging with the politics of sustainability transitions, Environ. Innov. Soc. Transitions. 1 (2011) 70-75. doi:10.1016/j.eist.2011.02.003.

[108] D. Messner, A social contract for low carbon and sustainable development, Technol. Forecast. Soc. Change. 98 (2015) 260-270. doi:10.1016/j.techfore.2015.05.013.

[109] WBGU, World in Transition - A Social Contract for Sustainability, German Advisory Council on Global Change, Berlin, 2011.

[110] E. Krick, Ensuring social acceptance of the energy transition. The German government's 'consensus management' strategy, J. Environ. Policy Plan. 20 (2018) 64-8o. doi:10.1080/1523908X.2017.1319264.

[111] S. Bushell, M. Workman, T. Colley, Grantham Institute Briefing paper No 18: Towards a unifying narrative for climate change, Imperial College London, 
London, UK, 2016. http://www.imperial.ac.uk/media/imperial-

college/grantham-institute/public/publications/briefing-papers/Towards-aunifying-narrative-for-climate-change-Grantham-BP18.pdf.

[112] S. Bushell, T. Colley, M. Workman, A unified narrative for climate change, Nat. Clim. Chang. 5 (2015) 971-973. doi:10.1038/nclimate2726.

[113] G. Kallis, In defence of degrowth, Ecol. Econ. 70 (2011) 873-880. doi:10.1016/j.ecolecon.2010.12.007.

[114] E. Patashnik, After the Public Interest Prevails: The Political Sustainability of Policy Reform, Governance. 16 (2003) 203-234. doi:10.1111/1468-0491.00214.

[115] M. Lockwood, The political sustainability of climate policy: The case of the UK Climate Change Act, Glob. Environ. Chang. 23 (2013) 1339-1348. doi:10.1016/j.gloenvcha.2013.07.001.

[116] P.Z. Grossman, Energy shocks, crises and the policy process: A review of theory and application, Energy Policy. 77 (2015) 56-69.

doi:10.1016/j.enpol.2014.11.031.

[117] E.M. Rogers, Diffusion of Innovations, 5th Editio, Free Press Simon and Schuster, New York, NY, USA, 2003.

http://www.simonandschuster.com/books/Diffusion-of-Innovations-5thEdition/Everett-M-Rogers/9780743222099.

[118] E. Katz, The Two-Step Flow of Communication: An Up-To-Date Report on an Hypothesis, Public Opin. Q. 21 (1957) 61. doi:10.1086/266687.

[119] CCC, The Fourth Carbon Budget: Reducing Emissions through the 20205, The Committee on Climate Change (CCC), London, UK, 2010.

https://www.theccc.org.uk/publication/the-fourth-carbon-budget-reducingemissions-through-the-2020s-2/.

[120] T. Hargreaves, A. Haxeltine, N. Longhurst, G. Seyfang, Sustainability transitions from the bottom-up: Civil society, the multi-level perspective and practice theory, CSERGE Working Paper 2011-01, CSERGE Working Papers, University of East Anglia, The Centre for Social and Economic Research on the Global Environment (CSERGE), Norwich, 2011. https://www.econstor.eu/handle/10419/48796.

[121] C.A. McAlpine, L.M. Seabrook, J.G. Ryan, B.J. Feeney, W.J. Ripple, A.H. Ehrlich, P.R. Ehrlich, Transformational change: creating a safe operating space for humanity, Ecol. Soc. 20 (2015) art56. doi:10.5751/ES-07181-200156.

[122] K. O'Brien, Global environmental change II: From adaptation to deliberate transformation, Prog. Hum. Geogr. 36 (2012) 667-676. doi:10.1177/0309132511425767.

[123] K. O'Brien, L. Sygna, Responding to Climate Change: The Three Spheres of Transformation, in: Proc. Transform. a Chang. Clim., University of Oslo, Oslo, 
Norway, 2013: pp. 16-23. http://cchange.no/wp-content/uploads/2013/12/1Responding-to-climate-change-Three-spheres-oftransformation\%7B_\%7DOBrien-andSygna\%7B_\%7Dwebversion\%7B_\%7DFINAL.pdf.

[124] R.W. Fri, M.L. Savitz, Rethinking energy innovation and social science, Energy Res. Soc. Sci. 1 (2014) 183-187. doi:10.1016/j.erss.2014.03.010.

[125] D. Ürge-Vorsatz, A. Novikova, S. Köppel, B. Boza-Kiss, Bottom-up assessment of potentials and costs of $\mathrm{CO}_{2}$ emission mitigation in the buildings sector: insights into the missing elements, Energy Effic. 2 (2009) 293-316. doi:10.1007/s12053-009-9051-0.

[126] H. Huntington, L. Schipper, A.H. Sanstad, Editors' introduction, Energy Policy. 22 (1994) 795-797. doi:10.1016/0301-4215(94)90136-8.

[127] A.B. Jaffe, R.G. Newell, R.N. Stavins, Economics of Energy Efficiency, in: Encycl. Energy, Elsevier, 2004: pp. 79-9o. doi:10.1016/Bo-12-176480-X/00228$X$.

[128] K. Gillingham, R.G. Newell, K. Palmer, Energy Efficiency Economics and Policy, Annu. Rev. Resour. Econ. 1 (2009) 597-620. doi:10.1146/annurev.resource.102308.124234.

[129] M.S. Morgan, Model Experiements and Models in Experiements, in: L. Magnani, N.J. Nersessian (Eds.), Model. Reason. Sci. Technol. Values, Proc. Int. Conf. Model. Reason. Sci. Discov. Technol. Innov. Values Held May 17-19, 2001, Pavia, Italy, Kluwer Academic / Plenum Publishers, New York, 2002: pp. 41-58.

[130] U. Mäki, Models are experiments, experiments are models, J. Econ. Methodol. 12 (2005) 303-315. doi:10.1080/13501780500086255.

[131] S. Theodoridis, Monte Carlo Methods, in: Mach. Learn., Elsevier, 2015: pp. 707744. doi:10.1016/B978-0-12-801522-3.00014-8.

[132] S. Pye, N. Sabio, N. Strachan, An integrated systematic analysis of uncertainties in UK energy transition pathways, Energy Policy. 87 (2015) 673684. doi:10.1016/j.enpol.2014.12.031.

[133] H. Pollitt, J.-F. Mercure, The role of money and the financial sector in energyeconomy models used for assessing climate and energy policy, Clim. Policy. (2017) 1-14. doi:10.1080/14693062.2016.1277685.

[134] W. Throop, M. Mayberry, Leadership for the Sustainability Transition, Bus. Soc. Rev. 122 (2017) 221-250. doi:10.1111/basr.12116.

[135] D. Loorbach, K. Wijsman, Business transition management: exploring a new role for business in sustainability transitions, J. Clean. Prod. 45 (2013) 20-28. doi:10.1016/j.jclepro.2012.11.002.

[136] P. Mau, J. Eyzaguirre, M. Jaccard, C. Collins-Dodd, K. Tiedemann, The 
'neighbor effect": Simulating dynamics in consumer preferences for new vehicle technologies,' Ecol. Econ. 68 (2008) 504-516.

doi:10.1016/j.ecolecon.2008.05.007.

[137] E. Amel, C. Manning, B. Scott, S. Koger, Beyond the roots of human inaction: Fostering collective effort toward ecosystem conservation, Science (80-. ). 356 (2017) 275-279. doi:10.1126/science.aal1931.

[138] J.-F. Mercure, Fashion, fads and the popularity of choices: Micro-foundations for diffusion consumer theory, Struct. Chang. Econ. Dyn. 46 (2018) 194-207. doi:10.1016/j.strueco.2018.06.001.

[139] K. Dahle, When do transformative initiatives really transform? A typology of different paths for transition to a sustainable society, Futures. 39 (2007) 487504. doi:10.1016/j.futures.2006.10.007.

[140] D. Helbing, Economics 2.0: The Natural Step towards a Self-Regulating, Participatory Market Society, Evol. Institutional Econ. Rev. 10 (2013) 3-41. doi:10.14441/eier.D2013002.

[141] H. Tibbs, Changing cultural values and the transition to sustainability, J. Futur. Stud. 15 (2011) 13-32. https://jfsdigital.org/wp-content/uploads/2014/01/153A02.pdf.

[142] J. Norwine, Introduction: Imagining the Unimaginable, in: A World After Clim. Chang. Cult., Springer Netherlands, Dordrecht, 2014: pp. 1-11. doi:10.1007/978-94-007-7353-0_1.

[143] C. Riedy, Waking up in the twenty-first century, Horiz. 21 (2013) 174-186. doi:10.1108/OTH-03-2013-0016.

[144] S.C. Isley, R.J. Lempert, S.W. Popper, R. Vardavas, An Evolutionary Model of Industry Transformation and the Political Sustainability of Emission Control Policies, RAND Corporation, Santa Monica, CA, USA, 2013. https://www.rand.org/pubs/technical_reports/TR1308.html.

[145] S.C. Isley, R.J. Lempert, S.W. Popper, R. Vardavas, The effect of near-term policy choices on long-term greenhouse gas transformation pathways, Glob. Environ. Chang. 34 (2015) 147-158. doi:10.1016/j.gloenvcha.2015.06.008.

[146] C.E. Lindblom, The Science of "Muddling Through," Public Adm. Rev. 19 (1959) 79. doi:10.2307/973677.

[147] J.M. Wittmayer, F. Avelino, F. van Steenbergen, D. Loorbach, Actor roles in transition: Insights from sociological perspectives, Environ. Innov. Soc.

Transitions. 24 (2017) 45-56. doi:10.1016/j.eist.2016.10.003.

[148] House of Commons Environmental Audit Select Committee, Reducing Carbon Emissions from UK Business: the role of the Climate Change Levy and Agreements, UK Parliament, London, UK, 2008. https://publications.parliament.uk/pa/cm200708/cmselect/cmenvaud/354/3540 
2.htm.

[149] P. Ekins, G. Anandarajah, N. Strachan, Towards a low-carbon economy: scenarios and policies for the UK, Clim. Policy. 11 (2011) 865-882.

doi:10.3763/cpol.2010.0126.

[150] J. Andrew, M.A. Kaidonis, B. Andrew, Carbon tax: Challenging neoliberal solutions to climate change, Crit. Perspect. Account. 21 (2010) 611-618. doi:10.1016/j.cpa.2010.03.009.

[151] S. Frantzi, M. Kok, Governance and Institutions in Global Sustainability Modelling, in: Int. Stud. Assoc. 5oth Annu. Conv. "Exploring Past, Anticip. Futur., New York City, NY, USA, 2009.

[152] J. Patterson, K. Schulz, J. Vervoort, S. van der Hel, O. Widerberg, C. Adler, M. Hurlbert, K. Anderton, M. Sethi, A. Barau, Exploring the governance and politics of transformations towards sustainability, Environ. Innov. Soc. Transitions. 24 (2017) 1-16. doi:10.1016/j.eist.2016.09.001.

[153] M. Hajer, M. Nilsson, K. Raworth, P. Bakker, F. Berkhout, Y. de Boer, J. Rockström, K. Ludwig, M. Kok, Beyond Cockpit-ism: Four Insights to Enhance the Transformative Potential of the Sustainable Development Goals, Sustainability. 7 (2015) 1651-1660. doi:10.3390/su7021651. 